\title{
Integrative Analysis of miRNA and mRNA \\ Expression Profiles in Mammary Glands of Holstein Cows Artificially Infected with Staphylococcus Aureus
}

\author{
Xiaolong Wang \\ Yangzhou University \\ Yongliang Fan \\ Yangzhou University \\ Ziyin Han \\ Yangzhou University \\ Zaicheng Gong \\ Yangzhou University \\ Yalan Peng \\ Yangzhou University \\ Yongjiang Mao \\ Yangzhou University \\ Zhangping Yang \\ Yangzhou University \\ Yi Yang ( $\nabla$ yangyi@yzu.edu.cn ) \\ Yangzhou University
}

\section{Research Article}

Keywords: bovine mastitis, Staphylococcus aureus, differential expression microRNAs, differentially expressed genes, integrative analysis

Posted Date: February 1st, 2021

DOI: https://doi.org/10.21203/rs.3.rs-153895/v1

License: (c) (1) This work is licensed under a Creative Commons Attribution 4.0 International License. Read Full License 


\section{Abstract}

Background: Staphylococcus aureus-induced mastitis is one of the most intractable problems for dairy industry, which causes loss of milk yield and early slaughter of cows worldwide. Few study used a comprehensive approach based on the integrative analysis of miRNA and mRNA expression profiles to explore molecular mechanism in bovine mastitis caused by $S$. aureus.

Results: In this study, S. aureus and sterile phosphate buffered saline (PBS) were introduced to different quarters of breasts of three individuals, and transcriptome sequencing and microarrays were utilized to detected miRNA and gene expression in mammary gland from the challenged and control groups. A total of 77 differentially expressed microRNAs (DE miRNAs) and 1,625 differentially expressed genes (DEGs) were identified. Gene Ontology (GO) annotation and Kyoto Encyclopedia of Genes and Genomes (KEGG) pathway analysis showed that multiple DEGs were enriched in significant terms and pathways associated with immunity and inflammation. Integrative analysis between DE miRNAs and DEGs proved that miR-664b, miR-23b-3p, miR-331-5p, miR-19b and miR-2431-3p were potential factors regulating the expression levels of CD14 Molecule (CD14), G protein subunit gamma 2 (GNG2), interleukin 17A (IL17A), collagen type IV alpha 1 chain (COL4A1), microtubule associated protein RP/EB family member 2 (MAPRE2), member of RAS oncogene family (RAP1B), LDOC1 regulator of NFKB signaling (LDOC1), lowdensity lipoprotein receptor (LDLR) and S100 calcium binding protein A9 (S100A9) in bovine mastitis caused by $S$. aureus.

Conclusions: These findings could enhance the understanding of underlying immune response in bovine mammary glands against $S$. aureus infection, and provide a useful foundation for future application of the miRNA-mRNA based genetic regulatory network in the breeding cows resistant to $S$. aureus.

\section{Background}

Bovine mastitis compromises the health and welfare of dairy cattle, as well as decreases the quality and quantity of milk production, causing huge economic losses in the global dairy industry [1].

Staphylococcus aureus is a major etiological pathogen of bovine mastitis, causing a persistent and chronic infection and largely ineffective with antibiotic therapies [2,3]. The infectivity and antibiotic resistance of $S$. aureus makes bovine mastitis more difficult to control $[4,5]$. By breeding dairy cows with stronger resistance to udder disease, the risk of mastitis may be reduced in the dairy cow population [6]. Therefore, the identification of specific genes related to mastitis susceptibility or resistance can provide a new way to control mastitis through genetic selection $[7,8]$.

In recent years, numerous studies have shown that bovine mammary epithelial cells (BMECs) respond to the invasion of bacteria or bacterial products by altering the expression levels of several genes involved in inflammation and immunity in vitro [9-11]. However, one limitation of these studies that the conclusions drawn at cellular levels are not necessarily consistent with those of individuals [12]. Although some transcriptome-wide association studies have been carried out on $S$. aureus -induced mastitis in vivo, these 
studies always analyzed the expression levels of mRNAs or microRNAs (miRNAs) separately [13-17]. Few studies used a comprehensive approach based on the integrative analysis of miRNA and mRNA expression profiles to improve our understanding of the underlying molecular mechanism of cow mastitis caused by $S$. aureus.

To investigate various interaction networks and regulatory modes of mRNAs and miRNAs, we constructed a $S$. aureus-type bovine mastitis model and integrated the analysis of miRNAs and mRNAs between the $S$. aureus infected quarters and the control ones. These findings will provide new insights into the mechanism of $S$. aureus-induced cow mastitis.

\section{Results}

\section{The establishment of bovine S. aureus-induced mastitis model}

Indicators of the three cows were measured and recorded after bacterial infection. At $24 \mathrm{~h}$ post inoculation, the dairy cattle suffered from obvious pain and had a drastically reduction in milk yield. Besides, the temperature of cows raised and their mammary glands and lymph nodes were swollen and hard. At the same time, the alteration of the biophysical properties of milk (grey-white color) was observed. There were significant increases of SCC of the milk from inoculated quarters (A1: $1,790,000 / \mathrm{mL}, \mathrm{B} 1: 1,920,000 / \mathrm{mL}$ and $\mathrm{C} 1: 2,080,000 / \mathrm{mL}$ ), while those from the uninoculated quarters remained below $100,000 / \mathrm{mL}$.

\section{The pathological observation}

Compared with the control group, the mammary epithelial cells in the $S$. aureus inoculated group were loosely connected and had a lager intercellular space. A large number of inflammatory cells, including exhumed mammary epithelial cells, macrophages, neutrophils, and lymphocytes, are clustered in the acini (Figure 1).

\section{Differential Expressed miRNA Identification}

A total of $21,293,853$ and $18,588,177$ raw reads were generated from the control and $S$. aureus inoculated groups, respectively, by miRNA sequencing (Table S1). After raw reads disposing, there were 20,847,000 and $18,504,775$ clean reads for length distribution assessment. The assessment results revealed that the $78.76 \%$ and $71.79 \%$ of clean reads were $20 \sim 24$ nucleotides in length in the two groups (Figure S1). Principal component analysis (PCA) showed the miRNAs in the challenged and control groups can be classified into different clusters, respectively, indicating sequencing data is qualified for further analysis (Figure 2A). A total of 77 DE miRNAs, including 30 up-regulated and 47 down-regulated miRNAs, were identified in the $S$. aureus inoculated group compared with control group (Figure 3). 


\section{Differential Expressed mRNA Identification}

The 2100 RNA Integrity Number (RIN) and 28S/18S values were detected to evaluate the quality of RNAs. The values of 2100 RIN and 28S/18S were between 7.5 8.9 and 1.3 2.1, respectively (Table S2), indicating that the RNA quality met the requirement and could be used for marker hybridization.

The GeneSpring software (version 12.5, Agilent Technologies, the USA) was utilized to evaluate the coefficient of variation (CV) of each sample. In this study, the $\mathrm{CV}$ values of all samples ranged from $3.389 \%$ to $4.821 \%$ (Table S3), indicating that the detection results of the microarray is reliable.

PCA analysis was also performed to examine the sample distribution. Two clusters are found: $S$. aureus group and control group (Figure 2B). The transcriptional sequences of the same group were assembled in the same cluster, indicating that the main differences in the mRNA expression profiles occurred between different groups.

A total of 1,030 up-regulated genes and 595 down-regulated genes are identified in $S$. aureus group versus control group (Figure 3).

\section{Interaction Analysis of the miRNAs and mRNAs}

Three up-regulated and ten down-regulated DE miRNAs ( $P$-value $\leq 0.05$, fold difference $\geq 4$ ) were selected for the miRNA-mRNA interactive analysis. Among all potential target genes predicted by TargetScan, 143 up-regulated and 63 down-regulated genes identified in this study were employed for the construction of miRNA-mRNA interaction networks (Figure 4).

\section{Functional Analysis of Differentially Expressed Genes}

GO annotation based on three categories (biological processes (BP), molecular functions (MF) and cellular component (CC)) was performed to explore biological functions of DEGs regulated by DE miRNAs, in which there were 721 up-regulated and 381 down-regulated genes. The 721 up-regulated genes were significantly enriched in $174 \mathrm{BP}$ terms, $31 \mathrm{MF}$ terms and $25 \mathrm{CC}$ terms. Among them, 68 upregulated genes of 19 terms were involved in inflammation and immune response (Table 1). The 381 down-regulated genes were significantly enriched in 199 BP terms, 23 MF terms and 37 CC terms. Among them, 21 down-regulated genes of 25 terms were involved in inflammation and immune response. Only top 10 up-regulated and down-regulated terms in each category were listed in Figure 5. Features of DEGs enriched in top 9 significant GO terms were shown in Figure 6.

The 721 up-regulated genes were significantly enriched in 65 KEGG pathways, in which 22 pathways containing 119 up-regulated genes involved in inflammation and immune response (Table 2). The 381 down-regulated genes are significantly enriched in 26 KEGG pathways, in which 10 KEGG pathways containing 51 down-regulated genes involved in inflammation and immune response (Table 2). The top 
30 up-regulated and down-regulated pathways were listed in Figure 7. Features of DEGs enriched in top 9 significant KEGG terms were shown in Figure 8. 
Table 1

Significant terms involved in inflammation and immune response.

\begin{tabular}{|c|c|c|c|c|}
\hline Term ID & Term & $\begin{array}{l}P \\
\text { value }\end{array}$ & Gene Name & Number \\
\hline GO:0071310 & $\begin{array}{l}\text { cellular response to } \\
\text { organic substance }\end{array}$ & 0.009 & $\begin{array}{l}\text { CXCR1', GFPT2, CSF3, IL17A, PTGS2, } \\
\text { WNT2, CXCL5, IL2RA, OAS2, PTAFR, } \\
\text { PTGIS, ABHD2, RIPOR2, SOCS3, COL 1A2, } \\
\text { GNG2, COL1A1, SCARB1, LDLR, FYN, } \\
\text { ATP2B4, SNAI2, MSN, IRAK2, RAP1B, } \\
\text { WASF1, CD14, COLAA1, DERL1, HSPA5, } \\
\text { ACVR2A, LDOC1, EHD1, UFM1 }\end{array}$ & 34 \\
\hline GO:0051345 & $\begin{array}{l}\text { positive regulation } \\
\text { of hydrolase } \\
\text { activity }\end{array}$ & 0.010 & $\begin{array}{l}\text { SELE, S100A9, HTR2A, MAPRE2, AHSA2, } \\
\text { PYCARD, ABR, CHN1, DNAJB4, } \\
\text { ARHGAP15, SEC23A, ATP1B3, AGFG1, } \\
\text { ASAP1 }\end{array}$ & 14 \\
\hline GO:1901701 & $\begin{array}{l}\text { cellular response to } \\
\text { oxygen-containing } \\
\text { compound }\end{array}$ & 0.011 & $\begin{array}{l}\text { CXCL5, PTAFR, COL1A2, GNG2, COL1A1, } \\
\text { SCARB1, LDLR, FYN, ATP2B4, TXN, SNAI2, } \\
\text { MSN, IRAK2, RAP1B, CD14, COL4A1, } \\
\text { LDOC1, NCF1, SOD2 }\end{array}$ & 19 \\
\hline GO:0071216 & $\begin{array}{l}\text { cellular response to } \\
\text { biotic stimulus }\end{array}$ & 0.015 & $\begin{array}{l}\text { CXCL5, PTAFR, SCARB1, IRAK2, CD14, } \\
\text { HSPA5, LDOC1 }\end{array}$ & 7 \\
\hline GO:0071222 & $\begin{array}{l}\text { cellular response to } \\
\text { lipopolysaccharide }\end{array}$ & 0.015 & $\begin{array}{l}\text { CXCL5, PTAFR, SCARB1, IRAK2, CD14, } \\
\text { LDOC1 }\end{array}$ & 6 \\
\hline GO:0072676 & $\begin{array}{l}\text { lymphocyte } \\
\text { migration }\end{array}$ & 0.016 & RIPOR2, PYCARD, STK10, MSN & 4 \\
\hline GO:0032496 & $\begin{array}{l}\text { response to } \\
\text { lipopolysaccharide }\end{array}$ & 0.020 & $\begin{array}{l}\text { CXCL5, PTAFR, SCARB1, IRAK2, TBXA2R, } \\
\text { CD14, LDOC1 }\end{array}$ & 7 \\
\hline GO:0071219 & $\begin{array}{l}\text { cellular response to } \\
\text { molecule of } \\
\text { bacterial origin }\end{array}$ & 0.021 & $\begin{array}{l}\text { CXCL5, PTAFR, SCARB1, IRAK2, CD14, } \\
\text { LDOC1 }\end{array}$ & 6 \\
\hline G0:0030334 & $\begin{array}{l}\text { regulation of cell } \\
\text { migration }\end{array}$ & 0.023 & $\begin{array}{l}\text { SRPX2, PRR5L, ABHD2, RIPOR2, STC1, } \\
\text { MAPRE2, MMP14, PYCARD, COL 1A1, } \\
\text { STK10, SNAI2, MSN, TBXA2R, ITGB1, } \\
\text { HSPA5 }\end{array}$ & 15 \\
\hline GO:0071229 & $\begin{array}{l}\text { cellular response to } \\
\text { acid chemical }\end{array}$ & 0.028 & COL1A2, GNG2, COL1A1, LDLR, COL4A1 & 5 \\
\hline G0:0032729 & $\begin{array}{l}\text { positive regulation } \\
\text { of interferon- } \\
\text { gamma production }\end{array}$ & 0.028 & PYCARD, FAM49B, CD14 & 3 \\
\hline GO:0050900 & $\begin{array}{l}\text { leukocyte } \\
\text { migration }\end{array}$ & 0.030 & $\begin{array}{l}\text { SELE, IL17A, S100A9, CXCL5, RIPOR2, } \\
\text { PYCARD, STK10, MSN }\end{array}$ & 8 \\
\hline GO:0002237 & $\begin{array}{l}\text { response to } \\
\text { molecule of } \\
\text { bacterial origin }\end{array}$ & 0.031 & $\begin{array}{l}\text { CXCL5, PTAFR, SCARB1, IRAK2, TBXA2R, } \\
\text { CD14, LDOC1 }\end{array}$ & 7 \\
\hline
\end{tabular}




\begin{tabular}{|c|c|c|c|c|}
\hline GO:0030593 & $\begin{array}{l}\text { neutrophil } \\
\text { chemotaxis }\end{array}$ & 0.034 & S100A9, CXCL5, RIPOR2 & 3 \\
\hline G0:0072678 & $\mathrm{T}$ cell migration & 0.034 & RIPOR2, PYCARD, MSN & 3 \\
\hline GO:0006954 & $\begin{array}{l}\text { inflammatory } \\
\text { response }\end{array}$ & 0.038 & $\begin{array}{l}\text { IL17A, S100A9, THBS1, PTGS2, ALOX5AP, } \\
\text { CD163, PTGS1, PTAFR, PTGIS, SOCS3, } \\
\text { PYCARD, LDLR, IRAK2, CYBB }\end{array}$ & 14 \\
\hline G0:0030203 & $\begin{array}{l}\text { glycosaminoglycan } \\
\text { metabolic process }\end{array}$ & 0.040 & LYVE1, DSE, SLC35D1, UGDH & 4 \\
\hline GO:0050954 & $\begin{array}{l}\text { sensory perception } \\
\text { of mechanical } \\
\text { stimulus }\end{array}$ & 0.040 & RIPOR2, COL1A1, FYN, SNAI2 & 4 \\
\hline G0:0071230 & $\begin{array}{l}\text { cellular response to } \\
\text { amino acid } \\
\text { stimulus }\end{array}$ & 0.041 & COL1A2, COL1A1, COL4A1 & 3 \\
\hline G0:0006935 & chemotaxis & $<.001$ & $\begin{array}{l}\text { CXCL 11 }{ }^{\mathrm{b}}, \text { CXCL 10, F2RL 1, CXCL 9, MSTN, } \\
\text { NFIB, MET, CCL 5, PDGFA, CXCR3, SCN1B }\end{array}$ & 11 \\
\hline G0:0050921 & $\begin{array}{l}\text { positive regulation } \\
\text { of chemotaxis }\end{array}$ & $<.001$ & $\begin{array}{l}\text { CXCL 10, F2RL1, MSTN, MET, CCL5, } \\
\text { CXCR3 }\end{array}$ & 6 \\
\hline GO:0050920 & $\begin{array}{l}\text { regulation of } \\
\text { chemotaxis }\end{array}$ & $<.001$ & $\begin{array}{l}\text { CXCL10, F2RL1, MSTN, MET, CCL5, } \\
\text { CXCR3 }\end{array}$ & 6 \\
\hline G0:0032103 & $\begin{array}{l}\text { positive regulation } \\
\text { of response to } \\
\text { external stimulus }\end{array}$ & 0.001 & $\begin{array}{l}\text { CXCL 10, F2RL 1, MSTN, C3, MET, CCL 5, } \\
\text { CXCR3 }\end{array}$ & 7 \\
\hline GO:0050900 & $\begin{array}{l}\text { leukocyte } \\
\text { migration }\end{array}$ & 0.001 & $\begin{array}{l}\text { CXCL11, CXCL 10, F2RL1, MSTN, GATA3, } \\
\text { CCL5, CXCR3 }\end{array}$ & 7 \\
\hline GO:0060326 & cell chemotaxis & 0.004 & CXCL 11, CXCL 10, MSTN, MET, CCL5 & 5 \\
\hline GO:0002690 & $\begin{array}{l}\text { positive regulation } \\
\text { of leukocyte } \\
\text { chemotaxis }\end{array}$ & 0.005 & CXCL 10, MSTN, CCL5 & 3 \\
\hline G0:1990868 & $\begin{array}{l}\text { response to } \\
\text { chemokine }\end{array}$ & 0.005 & CX3CR1, CCL5, CXCR3 & 3 \\
\hline GO:1990869 & $\begin{array}{l}\text { cellular response to } \\
\text { chemokine }\end{array}$ & 0.005 & CX3CR1, CCL5, CXCR3 & 3 \\
\hline G0:0032101 & $\begin{array}{l}\text { regulation of } \\
\text { response to } \\
\text { external stimulus }\end{array}$ & 0.006 & $\begin{array}{l}\text { CXCL 10, F2RL 1, MSTN, S100B, C3, } \\
\text { GATA3, MET, CCL5, PDGFA, CXCR3 }\end{array}$ & 10 \\
\hline G0:0002688 & $\begin{array}{l}\text { regulation of } \\
\text { leukocyte } \\
\text { chemotaxis }\end{array}$ & 0.010 & CXCL 10, MSTN, CCL5 & 3 \\
\hline G0:0002685 & $\begin{array}{l}\text { regulation of } \\
\text { leukocyte } \\
\text { migration }\end{array}$ & 0.012 & CXCL 10, MSTN, CCL5, CXCR3 & 4 \\
\hline
\end{tabular}




\begin{tabular}{|c|c|c|c|c|}
\hline G0:0030595 & $\begin{array}{l}\text { leukocyte } \\
\text { chemotaxis }\end{array}$ & 0.013 & CXCL11, CXCL 10, MSTN, CCL5 & 4 \\
\hline G0:0002687 & $\begin{array}{l}\text { positive regulation } \\
\text { of leukocyte } \\
\text { migration }\end{array}$ & 0.016 & CXCL 10, MSTN, CCL5 & 3 \\
\hline G0:0007606 & $\begin{array}{l}\text { sensory perception } \\
\text { of chemical } \\
\text { stimulus }\end{array}$ & 0.027 & SCNN1G, SCNN1B & 2 \\
\hline G0:0036230 & $\begin{array}{l}\text { granulocyte } \\
\text { activation }\end{array}$ & 0.027 & F2RL 1, CCL 5 & 2 \\
\hline GO:0071622 & $\begin{array}{l}\text { regulation of } \\
\text { granulocyte } \\
\text { chemotaxis }\end{array}$ & 0.027 & MSTN, CCL5 & 2 \\
\hline GO:1905517 & $\begin{array}{l}\text { macrophage } \\
\text { migration }\end{array}$ & 0.027 & MSTN, CCL 5 & 2 \\
\hline GO:0002673 & $\begin{array}{l}\text { regulation of acute } \\
\text { inflammatory } \\
\text { response }\end{array}$ & 0.032 & $S 100 B, C 3$ & 2 \\
\hline GO:0050918 & $\begin{array}{l}\text { positive } \\
\text { chemotaxis }\end{array}$ & 0.034 & CXCL 10, MET, CCL 5 & 3 \\
\hline G0:0009605 & $\begin{array}{l}\text { response to } \\
\text { external stimulus }\end{array}$ & 0.039 & $\begin{array}{l}\text { CXCL 11, CXCL 10, F2RL1, CXCL9, MSTN, } \\
\text { S100B, C3, NFIB, REEP6, GATA3, AQP3, } \\
\text { MET, IKZF3, CCL5, PDGFA, CXCR3, SCN1B }\end{array}$ & 17 \\
\hline G0:0072678 & $\mathrm{T}$ cell migration & 0.043 & CXCL 11, CXCL 10 & 2 \\
\hline GO:2000401 & $\begin{array}{l}\text { regulation of } \\
\text { lymphocyte } \\
\text { migration }\end{array}$ & 0.048 & CXCL 10, CCL5 & 2 \\
\hline GO:1904062 & $\begin{array}{l}\text { regulation of cation } \\
\text { transmembrane } \\
\text { transport }\end{array}$ & 0.048 & CXCL 11, CXCL 10, CXCL9, CXCR3 & 4 \\
\hline G0:0042379 & $\begin{array}{l}\text { chemokine receptor } \\
\text { binding }\end{array}$ & $<0.001$ & CXCL11, CXCL 10, CXCL9, CCL5 & 4 \\
\hline
\end{tabular}


Table 2

Significant KEGG pathways involved in inflammation and immune response.

\begin{tabular}{|c|c|c|c|c|}
\hline $\begin{array}{l}\text { Pathway } \\
\text { ID }\end{array}$ & Pathway & $\begin{array}{l}P \\
\text { value }\end{array}$ & Gene Name & Number \\
\hline bta04666 & $\begin{array}{l}\text { Fc gamma R- } \\
\text { mediated } \\
\text { phagocytosis }\end{array}$ & $<.001$ & $\begin{array}{l}\text { PLA2G4A , MARCKSL1, VASP, SYK, PIK3R3, } \\
\text { FCGR1A, WASF1, CFL 1, ASAP1, NCF1, ARPC5, } \\
\text { LYN, ARPC2, MAP } 2 K 1\end{array}$ & 14 \\
\hline bta04668 & $\begin{array}{l}\text { TNF signaling } \\
\text { pathway }\end{array}$ & $\dot{0} 001$ & $\begin{array}{l}\text { CXCL2, SELE, MMP3, PTGS2, CXCL6, VEGFC, } \\
\text { SOCS3, MMP14, CASP3, LIF, CSF1, PIK3R3, } \\
\text { MAP3K8, TNFAIP3, MAP2K3, MAP2K1 }\end{array}$ & 16 \\
\hline bta04066 & $\begin{array}{l}\text { HIF-1 signaling } \\
\text { pathway }\end{array}$ & $<.001$ & $\begin{array}{l}\text { SERPINE1, LDHA, PFKFB3, PGK1, HIF1A, PFKP, } \\
\text { TFRC, PIK3R3, MKNK1, ALDOA, ENO1, ENO2, } \\
\text { CYBB, MAP2K1 }\end{array}$ & 14 \\
\hline bta04015 & $\begin{array}{l}\text { Rap1 signaling } \\
\text { pathway }\end{array}$ & $<.001$ & $\begin{array}{l}\text { ITGAM, THBS1, PDGFRA, ID1, ITGB3, PDGFD, } \\
\text { VEGFC, APBB1IP, FYB, PDGFRB, VASP, CSF1, } \\
\text { PIK3R3, SIPA1L2, RAP1B, PFN1, MAP2K3, } \\
\text { ITGB1, TLN1, PRKD3, MAP2K1 }\end{array}$ & 21 \\
\hline bta04657 & $\begin{array}{l}\text { IL-17 signaling } \\
\text { pathway }\end{array}$ & $<.001$ & $\begin{array}{l}\text { CXCL2, CSF3, IL17A, MMP3, S100A9, FOSL1, } \\
\text { PTGS2, CXCL6, MMP1, CASP3, TNFAIP3, } \\
\text { MAPK6 }\end{array}$ & 12 \\
\hline bta05020 & Prion diseases & 0.001 & $\begin{array}{l}\text { NCAM1, LAMC1, FYN, PRKACB, HSPA5, } \\
\text { MAP2K1 }\end{array}$ & 6 \\
\hline bta04664 & $\begin{array}{l}\text { Fc epsilon RI } \\
\text { signaling pathway }\end{array}$ & 0.002 & $\begin{array}{l}\text { ALOX5AP, FCER1A, PLA2G4A, FYN, SYK, } \\
\text { PIK3R3, MAP2K3, LYN, MAP2K1 }\end{array}$ & 9 \\
\hline bta04151 & $\begin{array}{l}\text { PI3K-Akt signaling } \\
\text { pathway }\end{array}$ & 0.002 & $\begin{array}{l}\text { CSF3, THBS2, BDNF, THBS1, ITGA5, IL2RA, } \\
\text { PDGFRA, EPOR, ITGB3, PDGFD, VEGFC, } \\
\text { COL1A2, LAMA4, ITGA9, LAMC1, GNG2, } \\
\text { COL1A1, PDGFRB, CSF1, SYK, PIK3R3, } \\
\text { YWHAG, GNB4, COL4A1, ITGB1, CDK2, } \\
\text { MAP2K1 }\end{array}$ & 27 \\
\hline bta05134 & Legionellosis & 0.002 & $\begin{array}{l}\text { CXCL2, ITGAM, NAIP, CASP3, PYCARD, HSPA8, } \\
\text { CD14, SAR1A }\end{array}$ & 8 \\
\hline bta05146 & Amoebiasis & 0.002 & $\begin{array}{l}\text { SERPINB4, CXCL2, ITGAM, COL1A2, CASP3, } \\
\text { LAMA4, LAMC1, COL1A1, PRKACB, PIK3R3, } \\
\text { CD14, COL4A1 }\end{array}$ & 12 \\
\hline bta04670 & $\begin{array}{l}\text { Leukocyte } \\
\text { transendothelial } \\
\text { migration }\end{array}$ & 0.005 & $\begin{array}{l}\text { ITGAM, MMP2, JAM3, VASP, PIK3R3, MSN, } \\
\text { RAP1B, PTPN11, ITGB1, NCF1, CYBB }\end{array}$ & 11 \\
\hline bta04062 & $\begin{array}{l}\text { Chemokine } \\
\text { signaling pathway }\end{array}$ & 0.007 & $\begin{array}{l}\text { CXCR2, CXCL2, CCR1, CXCL6, CCL 16, PREX1, } \\
\text { GNG2, ARRB2, PRKACB, PIK3R3, RAP1B, } \\
\text { GNB4, NCF1, LYN, MAP2K1 }\end{array}$ & 15 \\
\hline bta05100 & $\begin{array}{l}\text { Bacterial invasion } \\
\text { of epithelial cells }\end{array}$ & 0.008 & $\begin{array}{l}\text { ITGA5, CBL, PIK3R3, WASF1, DNM3, ITGB1, } \\
\text { ARPC5, ARPC2 }\end{array}$ & 8 \\
\hline
\end{tabular}




\begin{tabular}{|c|c|c|c|}
\hline bta04145 & Phagosome & 0.008 & $\begin{array}{l}\text { THBS2, ITGAM, THBS1, ITGA5, ITGB3, } \\
\text { SCARB1, TUBB3, TFRC, FCGR1A, CD14, ITGB1, } \\
\text { ATP6V1C1, NCF1, CYBB }\end{array}$ \\
\hline bta05165 & $\begin{array}{l}\text { Human } \\
\text { papillomavirus } \\
\text { infection }\end{array}$ & 0.011 & $\begin{array}{l}\text { THBS2, THBS1, PTGS2, WNT2, ITGA5, ITGB3, } \\
\text { PKM, COL 1A2, CASP3, LAMA4, ITGA9, LAMC1, } \\
\text { COL1A1, PDGFRB, PRKACB, NOTCH2, PIK3R3, } \\
\text { COL4A1, MX2, ITGB1, ATP6V1C1, CDK2, } \\
\text { MAP2K1 }\end{array}$ \\
\hline
\end{tabular}

$\begin{aligned} \text { bta05167 } & \begin{array}{l}\text { Kaposi sarcoma- } \\ \text { associated } \\ \text { herpesvirus } \\ \text { infection }\end{array}\end{aligned}$

CXCL2, CCR1, PTGS2, E2F3, CASP3, PREX1, 15 GNG2, HIF1A, RCAN1, SYK, PIK3R3, GNB4, MAPKAPK2, LYN, MAP2K1

bta05323 $\begin{aligned} & \text { Rheumatoid } \\ & \text { arthritis }\end{aligned} \quad 0.023 \begin{aligned} & \text { CXCL2, IL17A, MMP3, CXCL6, MMP1, CD80, } \\ & \text { CSF1, ATP6V1C1, IL11 }\end{aligned}$

bta04392 $\begin{aligned} & \text { Hippo signaling } \\ & \text { pathway-multiple }\end{aligned} \quad 0.026 \quad$ RASSF2, WTIP, TEAD3, WWTR1

species

\begin{tabular}{|c|c|c|c|c|}
\hline bta04014 & $\begin{array}{l}\text { Ras signaling } \\
\text { pathway }\end{array}$ & 0.030 & $\begin{array}{l}\text { BDNF, PDGFRA, PDGFD, VEGFC, PLA2G4A, } \\
\text { GNG2, PDGFRB, PRKACB, CSF1, PIK3R3, } \\
\text { RAP1B, GNB4, ABL1, PTPN11, ABL2, MAP2K1 }\end{array}$ & 16 \\
\hline bta04061 & $\begin{array}{l}\text { Viral protein } \\
\text { interaction with } \\
\text { cytokine and } \\
\text { cytokine receptor }\end{array}$ & 0.033 & $\begin{array}{l}\text { CXCR2, CXCL2, CCR1, CXCL6, IL2RA, CCL16, } \\
\text { IL10RA, CSF1 }\end{array}$ & 8 \\
\hline bta05140 & Leishmaniasis & 0.033 & $\begin{array}{l}\text { ITGAM, PTGS2, MARCKSL1, FCGR1A, ITGB1, } \\
\text { NCF1, CYBB }\end{array}$ & 7 \\
\hline bta05145 & Toxoplasmosis & 0.035 & $\begin{array}{l}\text { IL10RA, CASP3, LAMA4, LAMC1, LDLR, } \\
\text { SOCS1, MAP2K3, HSPA8, ITGB1 }\end{array}$ & 9 \\
\hline bta04060 & $\begin{array}{l}\text { Cytokine-cytokine } \\
\text { receptor } \\
\text { interaction }\end{array}$ & $<.001$ & $\begin{array}{l}\text { CXCL11 } 1^{\mathrm{b}}, \text { CX3CR1, CXCL 10, CXCL9, NGFR, } \\
\text { CXCL 14, MSTN, XCL 1, IL 17RE, BMP3, } \\
\text { TNFRSF9, TNFSF10, GHR, CXCR6, CCL5, } \\
\text { TNFRSF19, CXCR3, TGFB2 }\end{array}$ & 18 \\
\hline
\end{tabular}

$\begin{array}{llll}\text { bta04061 } & \begin{array}{l}\text { Viral protein } \\ \text { interaction with } \\ \text { cytokine and } \\ \text { cytokine receptor }\end{array} & 0.001 & \begin{array}{l}\text { CXCL11, CX3CR1, CXCL10, CXCL9, CXCL 14, } \\ \text { XCL1, TNFSF10, CCL5, CXCR3 }\end{array}\end{array}$

$\begin{array}{ll}\text { bta04062 } \begin{array}{l}\text { Chemokine } \\ \text { signaling pathway }\end{array} & 0.001 \begin{array}{l}\text { CXCL11, CX3CR1, CXCL10, CXCL9, CXCL 14, } \\ \text { XCL1, ITK, PRKCZ, CXCR6, CCL5, CXCR3 }\end{array}\end{array}$

\begin{tabular}{|clclc} 
bta04015 & $\begin{array}{l}\text { Rap1 signaling } \\
\text { pathway }\end{array}$ & 0.004 & $\begin{array}{l}\text { FGFR4, NGFR, PRKCZ, FGFR2, MET, LPAR2, } \\
\text { TLN2, INSR, PDGFA, MAGI3, CTNND1 }\end{array}$ & 11 \\
\hline bta04670 & $\begin{array}{l}\text { Leukocyte trans } \\
\text { endothelial } \\
\text { migration }\end{array}$ & 0.007 & CLDN1, ITK, OCLN, CLDN3, TXK, EZR, CTNND1 & 7 \\
\hline
\end{tabular}

bta05340 Primary
immunodeficiency 


\begin{tabular}{|c|c|c|c|c|}
\hline bta01521 & $\begin{array}{l}\text { EGFR tyrosine } \\
\text { kinase inhibitor } \\
\text { resistance }\end{array}$ & 0.020 & ERBB3, FGFR2, MET, PDGFA, GAB1 & 5 \\
\hline bta04010 & $\begin{array}{l}\text { MAPK signaling } \\
\text { pathway }\end{array}$ & 0.028 & $\begin{array}{l}\text { FGFR4, ERBB3, NGFR, RPS6KA6, FGFR2, MET, } \\
\text { INSR, MAP3K13, PDGFA, MAP3K1, TGFB2 }\end{array}$ & 11 \\
\hline bta04390 & $\begin{array}{l}\text { Hippo signaling } \\
\text { pathway }\end{array}$ & 0.034 & $\begin{array}{l}\text { RASSF6, PRKCZ, DLG3, PPP2R2B, TCF7, } \\
\text { TCF7L2, TGFB2 }\end{array}$ & 7 \\
\hline bta04151 & $\begin{array}{l}\text { PI3K-Akt signaling } \\
\text { pathway }\end{array}$ & 0.035 & $\begin{array}{l}\text { FGFR4, ERBB3, NGFR, GHR, FGFR2, PPP2R2B, } \\
\text { MET, LPAR2, INSR, ITGA6, LAMC2, PDGFA, } \\
\text { ITGA3 }\end{array}$ & 13 \\
\hline
\end{tabular}

\section{Verification of DE miRNAs and DEGs by qRT-PCR}

To verify the accuracy of RNA sequencing and microarray, qRT-PCR is performed to detect the expression levels of miRNA and DEGs. The results showed that the relative expression levels of selected miRNAs and mRNAs identified by qRT-PCR were consistent with RNA sequencing and microarray results, respectively (Table S4 and S5), indicating a high reliability of the study.

\section{Discussion}

To date, more than 150 pathogenic bacteria have been identified in dairy cows with mastitis, among them, Escherichia coli, Streptococcus spp. and S. aureus were most frequently isolated from cows with clinical or subclinical mastitis [18]. In this study, the $S$. aureus-type bovine mastitis model was constructed to explore interaction patterns of mRNAs and miRNAs in the $S$. aureus infected quarters and the control ones. One quarter of each individual received the inoculation of $S$. aureus and the remaining quarters with the inoculation of PBS were served as control group. In this way, the systematic errors can be well minimized when we analyzed and compared the expression levels of mRNAs and miRNAs between inoculated and control groups $[19,20]$. In total, 77 DE miRNAs and 1,625 DEGs were identified in the $S$. aureus challenged quarters.

A previous study showed that the mutation of miR-664b, which was down-regulated in $S$. aureus infected quarters $(0.450$ fold change, $P<0.001)$, is associated with different epidemiological and clinical characteristics of cancer [21]. Accordingly, CD14 Molecule (CD14), which was identified as a predicted target of miR-664b was up-regulated in $S$. aureus infected quarters ( 2.151 fold change, $P=0.002$ ) (Table 
S6). This result is consistent with previous studies, in which CD14 was measured an up-regulated trend as an early innate immune response gene in bacterial infections of mammary gland [9, 22, 23]. CD14 is a lipopolysaccharide-binding protein and functions as an endotoxin receptor, and enriched significantly in the inflammation-related term, including cellular response to organic substance term, cellular response to oxygen-containing compound term, cellular response to biotic stimulus term, cellular response to lipopolysaccharide term, response to lipopolysaccharide term and cellular response to molecule of bacterial origin term. This finding supports a point that miR-664b negatively regulates its target gene, $C D 14$, to mediate inflammation in mammary gland of dairy cattle infected by $S$. aureus.

G protein subunit gamma 2 (GNG2), another target gene of miR-664b, was up-regulated in S. aureus inoculated quarters ( 3.246 fold change, $P=0.020$ ), which is significantly enriched in 3 significant terms (cellular response to organic substance term, cellular response to oxygen-containing compound term and cellular response to acid chemical term) and 4 significant pathways (PI3K-Akt signaling pathway, chemokine signaling pathway, Kaposi sarcoma-associated herpesvirus infection pathway and Ras signaling pathway) (Table S6). These terms and pathways are mainly involved in inflammation response. Previous studies mainly focused on functional analysis of GNG2 in human malignant melanoma cells [24-26]. However, there is no direct evidence to prove the association between the up-regulation of GNG2 and the infection of $S$. aureus in mammary gland. The highly expressed GNG2 may also associated with the down-regulation of miR-23b-3p ( 0.223 fold change, $P<0.001)$, which were identified to be associated with various cancers, such as cervical cancer, renal cancer and pancreatic cancer [27-30]. Other upregulated DEGs regulated by miR-23b-3p in $S$. aureus infection group were collagen type IV alpha 1 chain (COL4A1) (2.272 fold change, $P=0.007)$, microtubule associated protein RP/EB family member 2 (MAPRE2) (5.500 fold change, $P=0.001)$ and member of RAS oncogene family (RAP1B) (2.548 fold change, $P=0.008$ ). Although COL $4 A 1, M A P R E 2$ and $R A P 1 B$ are respectively enriched in various inflammation -related terms and pathways, to our knowledge, there is no evidence to prove that they have a bearing on bovine mastitis infected by $S$. aureus.

The down-regulation of miR-664b have a potential association with the extremely significant upregulation of interleukin $17 A(I L 17 A)$ (18.584 fold change, $P<0.001)$, which plays a crucial role in the defense of gram-positive bacterial infection and inflammation development [31-33]. IL 17A is significantly enriched in the terms of cellular response to organic substance, leukocyte migration and inflammatory response, and the pathways of IL-17 signaling and rheumatoid arthritis, which indicated that IL $17 A$ potentially act as a functional gene in the defense of $S$. aureus infection in bovine mammary gland. Generally known, the expression level of a single gene can be regulated by multiple miRNAs [34]. As shown in this study, miR-331-5p, which targets IL $17 A$, was down-regulated in $S$. aureus -inoculated quarters $(0.273$ fold change, $P<0.001)$. At the same time, a single miRNA can also target multiple genes [34]. In this study, LDOC1 regulator of NFKB signaling (LDOC1), the target gene of miR-331-5p, which was up-regulated in infected group (2.114 fold change). $\angle D O C 1$ is significantly enriched in cellular response to organic substance term, cellular response to oxygen-containing compound term, cellular response to biotic stimulus term, cellular response to lipopolysaccharide term, response to lipopolysaccharide term, cellular response to molecule of bacterial origin term and response to molecule of bacterial origin term. 
Previous study has suggested that LDOC1 regulated the aggressive lung cancer by targeting PhosphoJAK2 [35]. Additionally, multiple studies have shown that LDOC1 can induce apoptosis [36-38]. Thus, it remains to be clarified the role of LDOC1 in $S$. aureus -induced apoptosis.

The down-regulation of miR-19b $(0.397$ fold change, $P<0.001)$ is potentially responsible for the upregulation of $\angle D O C 1$ in $S$. aureus -induced mastitis, which has been identified to be the candidate marker for lung cancer and diabetes $[39,40]$. The down-regulation of miR-19b is also observed to account for the down-regulation of low-density lipoprotein receptor $(L D L R)$ (2.976 fold change, $P=0.024)$, which is significantly enriched in cellular response to organic substance term, cellular response to oxygencontaining compound term, cellular response to acid chemical term, inflammatory response term and toxoplasmosis pathway and can develop inflammatory atherosclerosis [41].

S100 calcium binding protein A9 (S100A9) is a kind of pro-inflammatory factors, and the protein from exosomes in follicular fluid causes inflammation by NF-KB pathway activation in polycystic ovary syndrome $[42,43]$. In this study, the up-regulated S100A9 (10.631 fold change, $P=0.006)$ and downregulated predicted target miRNA - 2431-3p (0.459 fold change, $P=0.005)$ were screened in $S$. aureusinoculated quarters which is enriched in multiple significant inflammatory and immune-related pathways, including positive regulation of hydrolase activity pathway, leukocyte migration pathway, neutrophil chemotaxis pathway and inflammatory response pathway.

\section{Conclusions}

In the present study, we comprehensively analyzed the changes in miRNA and mRNA profiles of the mammary gland of dairy cattle under $S$. aureus inoculation. Overall, 77 DE miRNAs and 1,625 DEGs were identified in the $S$. aureus challenged quarters. Among them, predicted integrated regulatory network was constructed with miRNAs (miR-664b, miR-23b-3p, miR-331-5p, miR-19b and miR-2431-3p) and mRNAs (CD14, GNG2, COL4A1, MAPRE2, RAP1B, IL 17A, LDOC1, LDLR and S100A9), which were significantly associated with inflammation and immunity (Fig. 9). These findings could enhance the understanding of underlying immune response in bovine mammary glands against $S$. aureus infection, and provide a useful foundation for future application of the miRNA-mRNA based genetic regulatory network in the breeding cows resistant to $S$. aureus.

\section{Methods}

\section{Ethics Statement}

All experimental protocols in this study were reviewed and approved by the Institutional Animal Care and Use Committee of Yangzhou University (ZZCX2019-SYXY-056). All methods in this study were carried out according in accordance with the Administration of Affairs Concerning Experimental Animals published by the Ministry of Science and Technology of China. 


\section{Animals Selection}

Three apparently healthy and mastitis-free Holstein dairy cattle (A, B and C) were chosen from a dairy farm in Yangzhou, China. All the three cows were in the middle lactation term of first parity with a consistent history of milk somatic cell count (SCC) below 100,000/mL. The experiment was performed after one week in quarantine.

\section{Mastitis Model Construction}

For challenge infection study, aliquots from frozen stock cultures (S. aureus, ATCC29213) were plated on sheep blood agar and incubated at $37{ }^{\circ} \mathrm{C}$ for $18 \mathrm{~h}$ under $10 \% \mathrm{CO}_{2}$-enriched conditions. Bacterial suspensions for each pure culture were diluted in sterile phosphate buffered saline (PBS) (biosharp, China) to $1 \times 10^{7}$ Colony-Forming Units (CFU)/mL, using a spectrophotometer (Eppendorf, Germany) with a wavelength of $600 \mathrm{~nm}$. For challenged group, one quarter (A1, B1 and C1) of each of the three individuals received a dose of $5 \times 10^{7} \mathrm{CFU}$ of $S$. aureus and one of the remaining quarters (A2, B2 and C2) not administered with the $S$. aureus inoculation were served as control group that received $5 \mathrm{~mL}$ of sterile PBS $[16,44]$.

\section{Sample Collection and Total RNA Extraction}

The mammary tissues (1 2 g per quarter) were collected by sterile operation from two quarters per dairy cattle. Samples from challenged (A1, B1 and C1) and control (A2, B2 and C2) quarters were immediately frozen in liquid nitrogen before RNA extraction or stored in $10 \%$ formalin for hematoxylin and eosin (HE) staining.

Total RNA was extracted from 250 mg mammary tissues with mirVana ${ }^{\mathrm{TM}}$ RNA Isolation Kit (Applied Biosystems, USA) and purified with QIAGEN RNeasy ${ }^{\circledR}$ Kit (QIAGEN, Germany). The RNA quality was assessed using Agilent Bioanalyzer 2100 (Agilent Technologies, USA) and NanoDrop spectrophotometer (Thermo Fisher, USA). Total RNA samples were stored at $-70^{\circ} \mathrm{C}$. A total of $10 \mu \mathrm{g}$ per RNA sample was sent to a commercial sequencing laboratory (Oebiotech, China) for evaluating the expression levels of miRNA and mRNA.

\section{Pathological tests}

After $48 \mathrm{~h}$ of soaking, the samples were rinsed with water for $12 \mathrm{~h}$ and subjected to gradient alcohol dehydration, wax impregnation and embedding. HE staining was performed for 15 min after dewaxing and dewaxing and adequate washing. The pathological changes were visualized with a microscope (Nikon, Japan). 


\section{Small RNA Sequencing and Data Analysis}

Clean reads constructing the small RNA libraries were obtained by removing low-quality reads, adaptors and insufficient tags. Then the length distribution and sequences of the clean reads was summarized and analyzed, respectively. Ribosomal RNAs (rRNAs), transfer RNAs (tRNAs), and other non-coding RNAs were identified and removed based on GenBank (http://www.ncbi.nlm.nih.gov) and Rfamdatabase10.1 (http://rfam.xfam.org/). MiRNAs were identified through a BLASTN search against the miRBase18.0 (http://www.mirbase.org/) [45].

The miRNA counts was normalized as transcript per million (TPM) with the formula (number of reads per miRNA alignment) / (number of reads from the total sample alignment) $\times 10^{6}[46]$. The differentially expressed (DE) miRNAs in each sample were calculated with DEseq R package (1.18.0) with $P$-value $\leq$ 0.05 and fold change $\geq 2$ as the threshold.

\section{MRNA Analysis and Data Process}

Total RNA was reverse-transcribed to double-stranded complementary DNA (cDNA) and purified with QIAGEN RNeasy ${ }^{\circledR}$ Kit (QIAGEN, Germany), from which complementary RNAs (cRNAs) were synthesized and then labelled with cyanine-3-CTP. For the calculation of fluorescence molecule concentration and incorporation, the following formulas were employed: Cy3-concentration $(\mathrm{pmol} / \mu \mathrm{L})=\mathrm{A} 552 / 0.15$, and Cy3-incorproation $(\mathrm{pmol} / \mu \mathrm{g})=$ Cy3-concentration/cRNA concentration $(\mu \mathrm{g} / \mu \mathrm{L})$. Then the cRNA sample fragmentation and chip hybridization were conducted, and the chips were washed and scanned subsequently.

Feature Extraction software (version 10.7.1.1, Agilent Technologies) was employed to extract and analyze raw data from array images. Briefly, the raw data was normalized with the quantile algorithm and the resultant flag value of any probe is assigned as "Detected" only if there are no "Compromised" or "Not Detected". DEGs were identified with $P$-value $\leq 0.05$ and fold change $\geq 2$ as the threshold.

\section{MiRNA-mRNA Interaction Network Construction}

With the online software TargetScan (www.targetscan.org), the potential target genes of DE miRNAs ( $P \leq$ 0.05 and fold change $\geq 4$ ) were predicted and intersected with the DEGs identified by microarray test ( $P$ $\leq 0.05$ and fold change $\geq 4$ ). Then the miRNA-mRNA interaction networks were constructed and visualized with the DE miRNAs and screened genes by String (v11.0) database and Cytoscape (v3.7.2), respectively [47].

\section{Functional analysis of Differentially Expressed Genes}


DEGs regulated by DE miRNAs were screened to further understand their biological and metabolic pathways. Gene ontology (GO) annotation and Kyoto Encyclopedia of Genes and Genomes (KEGG) analysis were respectively performed with the DAVID 6.8 (https://david.ncifcrf.gov/) and KOBAS 3.0 (http://kobas.cbi.pku.edu.cn/index.php) using R based on the hypergeometric distribution [47]. Then the GO terms and KEGG pathways with $P$-value $\leq 0.05$ were significantly enriched in DEGs or the miRNA target genes.

\section{RT-qPCR Validation of DEGs and DE miRNAs}

To validate the RNA sequencing data, eight DEGs (DGAT2, FADS2, ALDH3A2, EHHADH, FASN, LPL, SCD and SLC27A6) and six DE miRNAs (bta-miR-196a, bta-miR-205, bta-miR-200b, bta-miR-223, bta-miR-184, bta-miR-1246) were selected and analyzed by RT-qPCR. All the specific primers were synthesized by Sangon Biotech (Shanghai, China) and described in Table S7 and S8. The LightCycler ${ }^{\circledR} 480 \otimes$ System (Roche, Switzerland) was applied to qRT-PCR with and SYBR Green PCR Master Mix (Takara, Japan). MiRNA/mRNA were normalized for bovine 18S rRNA/ $\beta$-actin. Relative expression was calculated using the $2^{-\Delta \Delta C t}$ method in all samples.

\section{Statistical Analysis}

Data were analyzed using GraphPad Prism 8 (GraphPad, USA) and presented as mean \pm standard deviation (SD). $P \leq 0.05$ indicated a significant difference.

\section{List Of Abbreviations}

s.aureus, Staphylococcus aureus; PBS, phosphate buffered saline; DE miRNAs, differentially expressed microRNAs; DEGs, differentially expressed genes; GO, Gene Ontology; KEGG, Kyoto Encyclopedia of Genes and Genomes; CD14, CD14 Molecule, GNG2, G protein subunit gamma 2; IL17A, interleukin 17A; COL4A1, collagen type IV alpha 1 chain; MAPRE2, microtubule associated protein RP/EB family member 2; RAP1B, member of RAS oncogene family; $L D O C 1, \angle D O C 1$ regulator of NFKB signaling; $L D L R$, low-density lipoprotein receptor, S100A9, S100 calcium binding protein A9; BMECs, bovine mammary epithelial cells; SCC, somatic cell count; CFU, Colony-Forming Units; HE, hematoxylin and eosin; rRNAs, ribosomal RNAs; tRNAs, transfer RNAs; TPM, transcript per million; cDNA, complementary DNA; cRNAs, complementary RNAs; RIN, RNA Integrity Number; CV, coefficient of variation; BP, biological processes; MF, molecular functions; $\mathrm{CC}$, cellular component.

\section{Declarations}

\section{Acknowledgments and funding}


This work was funded by Jiangsu Agriculture Science and Technology Innovation Fund (JASTIF) (CX(20)3089 to Y.Y.), The National Natural Science Foundation of China (32002263 to Y.Y.), The Basic Research Program of Jiangsu Province (BK20190881 to Y.Y.), The China Postdoctoral Science Foundation (2019M650126 to Y.Y.), The Natural Science Foundation of Jiangsu Higher Education Institutions of China (19KJB230001 to Y.Y.), The High-level Innovation and Entrepreneurship Talents Introduction Program of Jiangsu Province of China, and A Project Funded by the Priority Academic Program Development of Jiangsu Higher Education Institutions (PAPD).

\section{Authors' Contributions}

$Y Y$ and $Z Y$ designed the study and experiments; $X W$ and $Y F$ performed the experiments; $Z H, Z G$, $Y P$ and YM managed and analyzed the data; XW and YF prepared the original manuscript; $Y Y$ reviewed and revised the manuscript. All authors have read and agreed to the published version of the manuscript.

\section{Availability of data and materials}

All data generated or analysed during this study are included in this published article or additional supporting files.

\section{Ethics approval and consent to participate}

All experimental protocols in this study were reviewed and approved by the Institutional Animal Care and Use Committee of Yangzhou University (ZZCX2019-SYXY-056). All methods in this study were carried out according in accordance with the Administration of Affairs Concerning Experimental Animals published by the Ministry of Science and Technology of China.

\section{Consent for publication}

Not applicable.

\section{Conflicts of Interest}

The authors declare no conflict of interest.

\section{References}

1. Zhang L, Gao J, Barkema HW, Ali T, Liu G, Deng Y, Naushad S, Kastelic JP, Han B: Virulence gene profiles: alpha-hemolysin and clonal diversity in Staphylococcus aureus isolates from bovine clinical mastitis in China. BMC Vet Res 2018, 14(1):63. 
2. Sutra L, Poutrel B: Virulence factors involved in the pathogenesis of bovine intramammary infections due to Staphylococcus aureus. J Med Microbio/ 1994, 40(2):79-89.

3. Hwang SY, Park YK, Koo HC, Park YH: spa typing and enterotoxin gene profile of Staphylococcus aureus isolated from bovine raw milk in Korea. $J$ Vet Sci 2010, 11(2):125-131.

4. Lutzow YC, Donaldson L, Gray CP, Vuocolo T, Pearson RD, Reverter A, Byrne KA, Sheehy PA, Windon R, Tellam RL: Identification of immune genes and proteins involved in the response of bovine mammary tissue to Staphylococcus aureus infection. BMC Vet Res 2008, 4:18.

5. Oliver JP, Gooch CA, Lansing S, Schueler J, Hurst JJ, Sassoubre L, Crossette EM, Aga DS: Invited review: Fate of antibiotic residues, antibiotic-resistant bacteria, and antibiotic resistance genes in US dairy manure management systems. J Dairy Sci 2020, 103(2):1051-1071.

6. Huang J, Luo G, Zhang Z, Wang X, Ju Z, Qi C, Zhang Y, Wang C, Li R, Li J et al: iTRAQ-proteomics and bioinformatics analyses of mammary tissue from cows with clinical mastitis due to natural infection with Staphylococci aureus. BMC Genomics 2014, 15:839.

7. Bobbo T, Penasa M, Finocchiaro R, Visentin G, Cassandro M: Alternative somatic cell count traits exploitable in genetic selection for mastitis resistance in Italian Holsteins. J Dairy Sci 2018, 101(11):10001-10010.

8. Asselstine V, Miglior F, Suarez-Vega A, Fonseca PAS, Mallard B, Karrow N, Islas-Trejo A, Medrano JF, Canovas A: Genetic mechanisms regulating the host response during mastitis. J Dairy Sci 2019, 102(10):9043-9059.

9. Strandberg Y, Gray C, Vuocolo T, Donaldson L, Broadway M, Tellam R: Lipopolysaccharide and lipoteichoic acid induce different innate immune responses in bovine mammary epithelial cells. Cytokine 2005, 31(1):72-86.

10. Gunther J, Koczan D, Yang W, Nurnberg G, Repsilber D, Schuberth HJ, Park Z, Maqbool N, Molenaar A, Seyfert HM: Assessment of the immune capacity of mammary epithelial cells: comparison with mammary tissue after challenge with Escherichia coli. Vet Res 2009, 40(4):31.

11. Griesbeck-Zilch B, Meyer HH, Kuhn CH, Schwerin M, Wellnitz O: Staphylococcus aureus and Escherichia coli cause deviating expression profiles of cytokines and lactoferrin messenger ribonucleic acid in mammary epithelial cells. J Dairy Sci 2008, 91(6):2215-2224.

12. Fu Y, Zhou E, Liu Z, Li F, Liang D, Liu B, Song X, Zhao F, Fen X, Li D et al: Staphylococcus aureus and Escherichia coli elicit different innate immune responses from bovine mammary epithelial cells. Vet Immunol Immunopathol 2013, 155(4):245-252.

13. Li R, Zhang CL, Liao XX, Chen D, Wang WQ, Zhu YH, Geng XH, Ji DJ, Mao YJ, Gong YC et al: Transcriptome microRNA profiling of bovine mammary glands infected with Staphylococcus aureus. Int J Mol Sci 2015, 16(3):4997-5013.

14. Luoreng ZM, Wang XP, Mei CG, Zan LS: Expression profiling of peripheral blood miRNA using RNAseq technology in dairy cows with Escherichia coli-induced mastitis. Sci Rep 2018, 8(1):12693.

15. Kosciuczuk EM, Lisowski P, Jarczak J, Majewska A, Rzewuska M, Zwierzchowski L, Bagnicka E: Transcriptome profiling of Staphylococci-infected cow mammary gland parenchyma. BMC Vet Res 
2017, 13(1):161.

16. Luoreng ZM, Wang XP, Mei CG, Zan LS: Comparison of microRNA Profiles between Bovine Mammary Glands Infected with Staphylococcus aureus and Escherichia coli. Int J Bio/ Sci 2018, 14(1):87-99.

17. Pisanu S, Cacciotto C, Pagnozzi D, Puggioni GMG, Uzzau S, Ciaramella P, Guccione J, Penati M, Pollera C, Moroni $\mathrm{P}$ et al: Proteomic changes in the milk of water buffaloes (Bubalus bubalis) with subclinical mastitis due to intramammary infection by Staphylococcus aureus and by non-aureus staphylococci. Sci Rep 2019, 9(1):15850.

18. Yang Y, Peng Y, Jiang J, Gong Z, Zhu H, Wang K, Zhou Q, Tian Y, Qin A, Yang Z et al: Isolation and characterization of multidrug-resistant Klebsiella pneumoniae from raw cow milk in Jiangsu and Shandong provinces, China. Transbound Emerg Dis 2020.

19. Chen Z, Xia H, Shen H, Xu X, Arbab AAl, Li M, Zhang H, Mao Y, Yang Z: Pathological Features of Staphylococcus aureus Induced Mastitis in Dairy Cows and Isobaric-Tags-for-Relative-and-AbsoluteQuantitation Proteomic Analyses. J Agric Food Chem 2018, 66(15):3880-3890.

20. Zhang H, Jiang H, Fan Y, Chen Z, Li M, Mao Y, Karrow NA, Loor JJ, Moore S, Yang Z: Transcriptomics and ITRAQ-Proteomics Analyses of Bovine Mammary Tissue with Streptococcus agalactiae-Induced Mastitis. J Agric Food Chem 2018, 66(42):11188-11196.

21. Galka-Marciniak P, Urbanek-Trzeciak MO, Nawrocka PM, Dutkiewicz A, Giefing M, Lewandowska MA, Kozlowski P: Somatic Mutations in miRNA Genes in Lung Cancer-Potential Functional Consequences of Non-Coding Sequence Variants. Cancers 2019, 11(6).

22. Lahouassa H, Moussay E, Rainard P, Riollet C: Differential cytokine and chemokine responses of bovine mammary epithelial cells to Staphylococcus aureus and Escherichia coli. Cytokine 2007, 38(1):12-21.

23. Bannerman DD, Paape MJ, Goff JP, Kimura K, Lippolis JD, Hope JC: Innate immune response to intramammary infection with Serratia marcescens and Streptococcus uberis. Vet Res 2004, 35(6):681-700.

24. Yajima I, Kumasaka MY, Tamura H, Ohgami N, Kato M: Functional analysis of GNG2 in human malignant melanoma cells. J Dermatol Sci 2012, 68(3):172-178.

25. Yajima I, Kumasaka MY, Yamanoshita O, Zou C, Li X, Ohgami N, Kato M: GNG2 inhibits invasion of human malignant melanoma cells with decreased FAK activity. Am J Cancer Res 2014, 4(2):182-188.

26. Yajima I, Kumasaka MY, Naito Y, Yoshikawa T, Takahashi H, Funasaka Y, Suzuki T, Kato M: Reduced GNG2 expression levels in mouse malignant melanomas and human melanoma cell lines. $A m \mathrm{~J}$ Cancer Res 2012, 2(3):322-329.

27. Campos-Viguri GE, Peralta-Zaragoza O, Jimenez-Wences H, Longinos-Gonzalez AE, CastanonSanchez CA, Ramirez-Carrillo M, Camarillo CL, Castaneda-Saucedo E, Jimenez-Lopez MA, MartinezCarrillo DN et al: MiR-23b-3p reduces the proliferation, migration and invasion of cervical cancer cell lines via the reduction of c-Met expression. Sci Rep 2020, 10(1):3256.

28. Zaman MS, Thamminana S, Shahryari V, Chiyomaru T, Deng G, Saini S, Majid S, Fukuhara S, Chang I, Arora $S$ et al: Inhibition of PTEN gene expression by oncogenic miR-23b-3p in renal cancer. PLoS One 
2012, 7(11):e50203.

29. Chen D, Wu X, Xia M, Wu F, Ding J, Jiao Y, Zhan Q, An F: Upregulated exosomic miR23b3p plays regulatory roles in the progression of pancreatic cancer. Oncol Rep 2017, 38(4):2182-2188.

30. Grieco FA, Sebastiani G, Juan-Mateu J, Villate O, Marroqui L, Ladriere L, Tugay K, Regazzi R, Bugliani M, Marchetti $P$ et al: MicroRNAs miR-23a-3p, miR-23b-3p, and miR-149-5p Regulate the Expression of Proapoptotic BH3-Only Proteins DP5 and PUMA in Human Pancreatic beta-Cells. Diabetes 2017, 66(1):100-112.

31. Nakada TA, Russell JA, Boyd JH, Walley KR: IL17A genetic variation is associated with altered susceptibility to Gram-positive infection and mortality of severe sepsis. Crit Care 2011, 15(5):R254.

32. Dominguez-Villar M, Hafler DA: Immunology. An innate role for IL-17. Science 2011, 332(6025):47-48.

33. Iwakura Y, Ishigame H, Saijo S, Nakae S: Functional specialization of interleukin-17 family members. Immunity 2011, 34(2):149-162.

34. Zhang G, Zou X, Liu Q, Xie T, Huang R, Kang H, Lai C, Zhu J: MiR-193a-3p functions as a tumour suppressor in human aldosterone-producing adrenocortical adenoma by down-regulating CYP11B2. Int J Exp Pathol 2018, 99(2):77-86.

35. Lee CH, Yang JR, Chen CY, Tsai MH, Hung PF, Chen SJ, Chiang SL, Chang H, Lin P: Novel STAT3 Inhibitor LDOC1 Targets Phospho-JAK2 for Degradation by Interacting with LNX1 and Regulates the Aggressiveness of Lung Cancer. Cancers 2019, 11(1).

36. Inoue M, Takahashi K, Niide O, Shibata M, Fukuzawa M, Ra C: LDOC1, a novel MZF-1-interacting protein, induces apoptosis. FEBS Lett 2005, 579(3):604-608.

37. Mizutani K, Koike D, Suetsugu S, Takenawa T: WAVE3 functions as a negative regulator of LDOC1. J biochem 2005, 138(5):639-646.

38. Salemi M, Barone N, La Vignera S, Condorelli RA, Recupero D, Galia A, Fraggetta F, Aiello AM, Pepe P, Castiglione $\mathrm{R}$ et al: Leucine zipper, down regulated in cancer-1 gene expression in prostate cancer. Oncol Lett 2016, 12(4):2796-2800.

39. Liu X, Zhang H, Zhang B, Zhang X: Expression and Role of MicroRNA-663b in Childhood Acute Lymphocytic Leukemia and its Mechanism. Open Med (Wars) 2019, 14:863-871.

40. He J, Kang Y, Lian C, Wu J, Zhou H, Ye X: Effect of miR-19b on the protective effect of Exendin-4 on islet cells in non-obese diabetic mice. Exp Ther Med 2019, 18(1):503-508.

41. Kiugel M, Hellberg S, Kakela M, Liljenback H, Saanijoki T, Li XG, Tuomela J, Knuuti J, Saraste A, Roivainen A: Evaluation of [(68)Ga]Ga-DOTA-TCTP-1 for the Detection of Metalloproteinase 2/9 Expression in Mouse Atherosclerotic Plaques. Molecules 2018, 23(12).

42. Ramadori G, Ljubicic S, Ricci S, Mikropoulou D, Brenachot X, Veyrat-Durebex C, Aras E, loris RM, Altirriba J, Malle E et al: S100A9 extends lifespan in insulin deficiency. Nat Commun 2019, 10(1):3545.

43. Li H, Huang X, Chang X, Yao J, He Q, Shen Z, Ji Y, Wang K: S100-A9 protein in exosomes derived from follicular fluid promotes inflammation via activation of NF-kappaB pathway in polycystic ovary 
syndrome. J Cell Mol Med 2020, 24(1):114-125.

44. Fang L, Hou Y, An J, Li B, Song M, Wang X, Sorensen P, Dong Y, Liu C, Wang Y et al: Genome-Wide Transcriptional and Post-transcriptional Regulation of Innate Immune and Defense Responses of Bovine Mammary Gland to Staphylococcus aureus. Front Cell Infect Microbio/ 2016, 6:193.

45. Pu J, Li R, Zhang C, Chen D, Liao X, Zhu Y, Geng X, Ji D, Mao Y, Gong Y et al: Expression profiles of miRNAs from bovine mammary glands in response to Streptococcus agalactiae-induced mastitis. $J$ Dairy Res 2017, 84(3):300-308.

46. Chen Z, Chu S, Wang X, Fan Y, Zhan T, Arbab AAl, Li M, Zhang H, Mao Y, Loor JJ et al: MicroRNA106b Regulates Milk Fat Metabolism via ATP Binding Cassette Subfamily A Member 1 (ABCA1) in Bovine Mammary Epithelial Cells. J Agric Food Chem 2019, 67(14):3981-3990.

47. Han Z, Fan Y, Yang Z, Loor JJ, Yang Y: Mammary Transcriptome Profile during Peak and Late Lactation Reveals Differentially Expression Genes Related to Inflammation and Immunity in Chinese Holstein. Animals (Basel) 2020, 10(3).

\section{Figures}



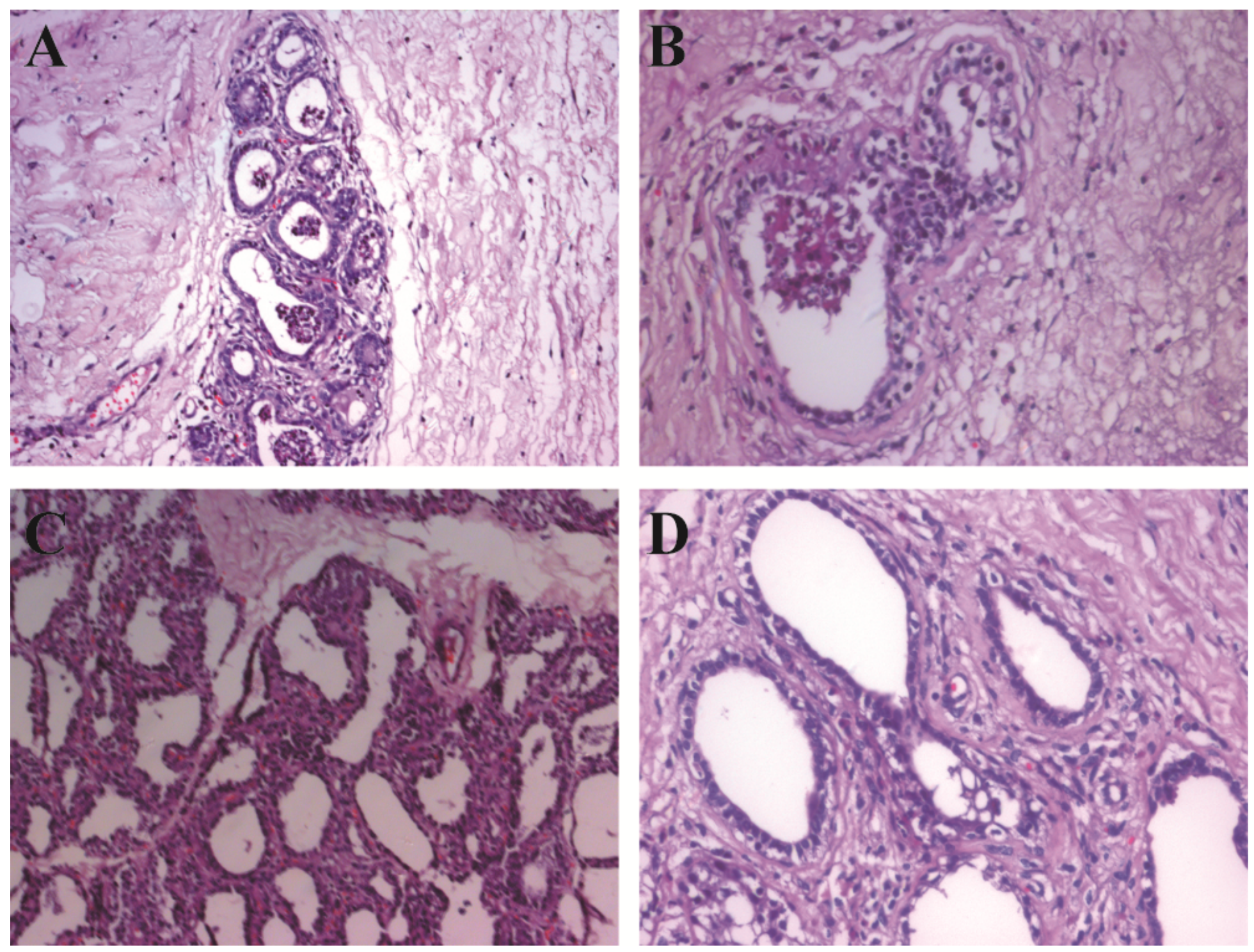

Figure 1

HE staining of mammary tissues. (A) Mammary tissues from the $S$. aureus- inoculated group with the infiltration of a large number of inflammatory cells, 200X. (B) Mammary tissues from the S. aureusinoculated group with the infiltration of a large number of inflammatory cells, 400X. (C) Mammary tissues from the control group with an integrated structure, 200X. (D) Mammary tissues from the control group with an integrated structure, 400X. 
A

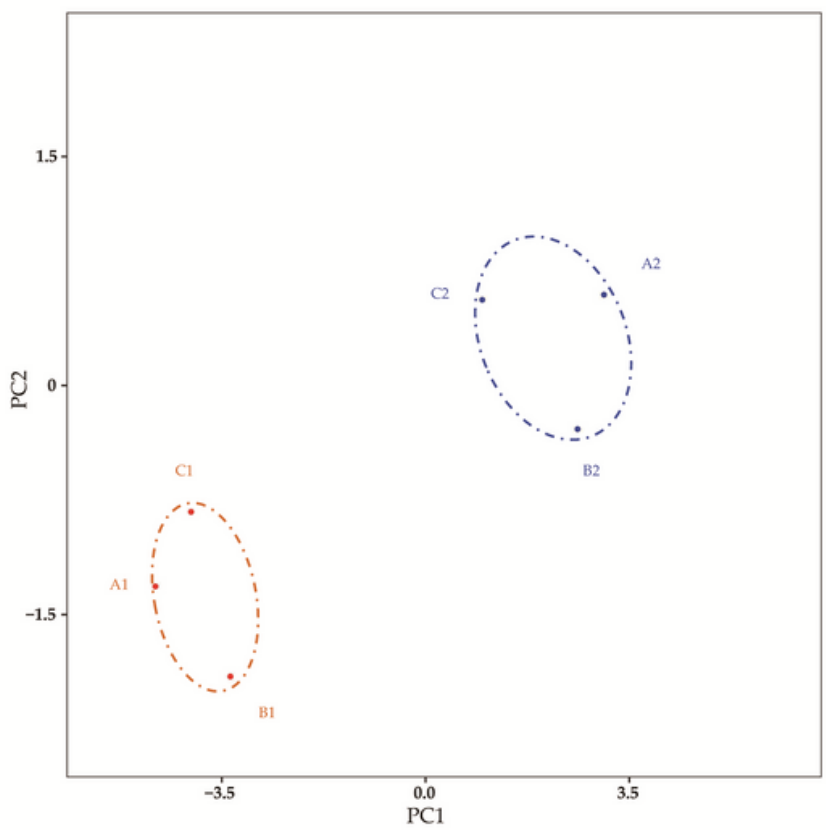

B

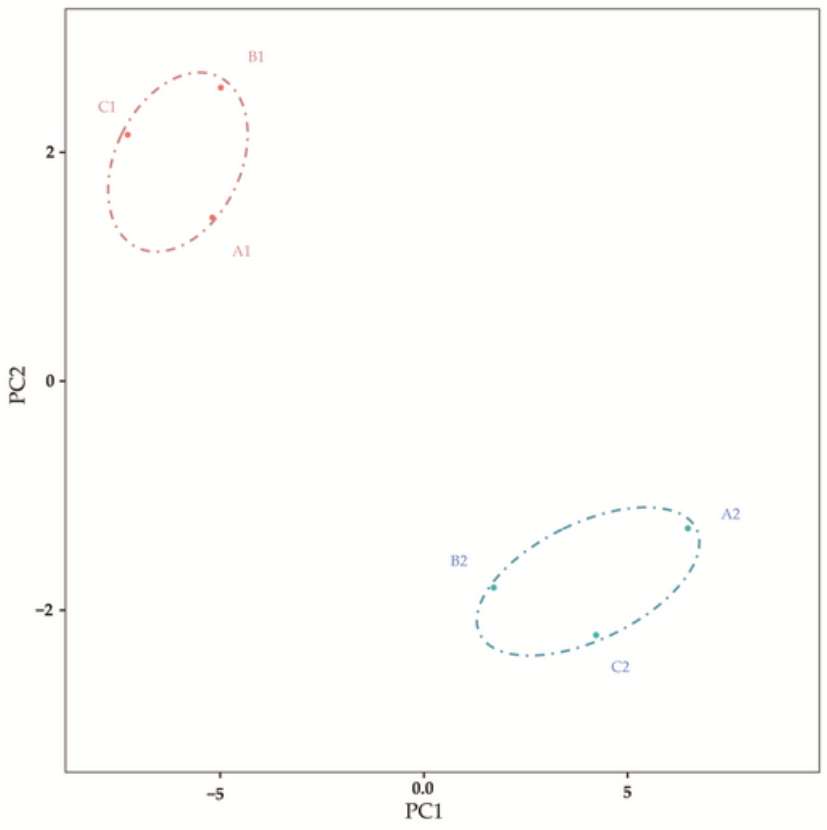

Figure 2

PCA analysis. (A) PCA analysis of miRNAs. (B) PCA analysis of mRNAs.

A

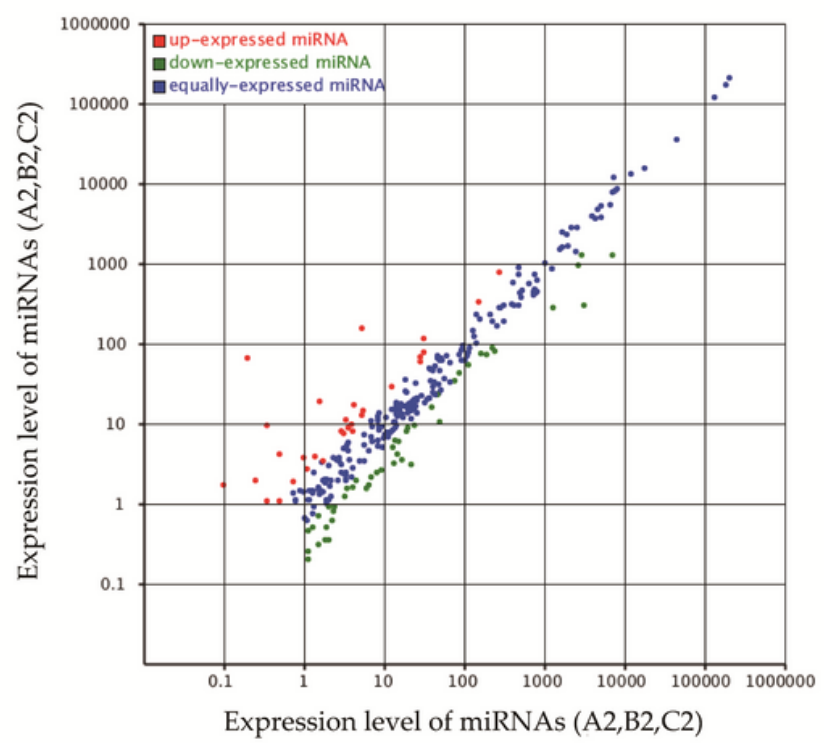

B

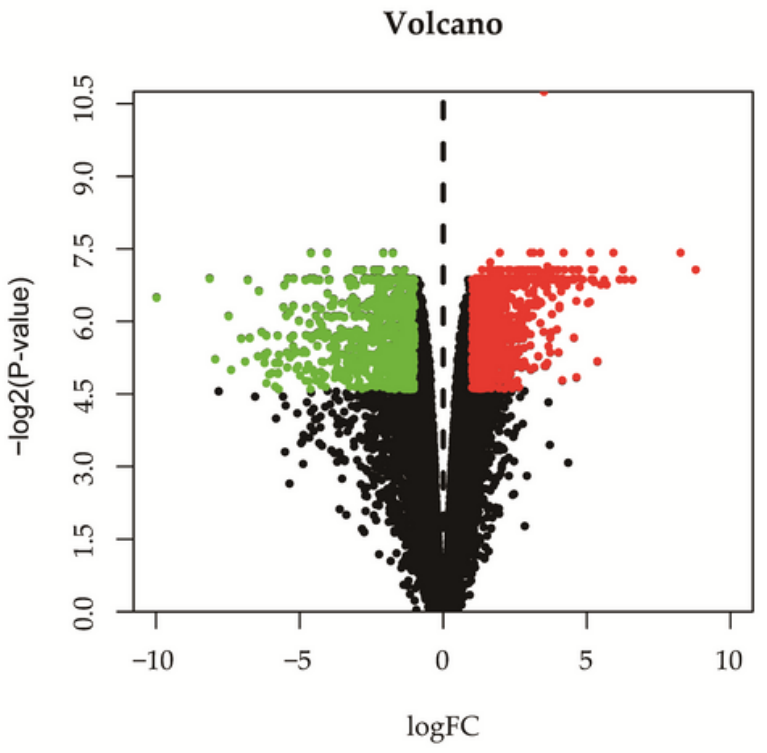

\section{Figure 3}

The volcano plots. (A) DE miRNAs in bovine mammary gland between the control group and S. aureusinoculated group. The up-regulated and down-regulated miRNAs were shown in red and blue dots, respectively, while the miRNAs with no significant difference in the two groups were shown in blue dots. (B) DEGs in bovine mammary gland between the control group and S. aureus- inoculated group. The up- 
regulated and down-regulated mRNAs were indicated by red and blue dots, respectively, which the mRNAs with no significant difference in the two groups were indicated by black dots.
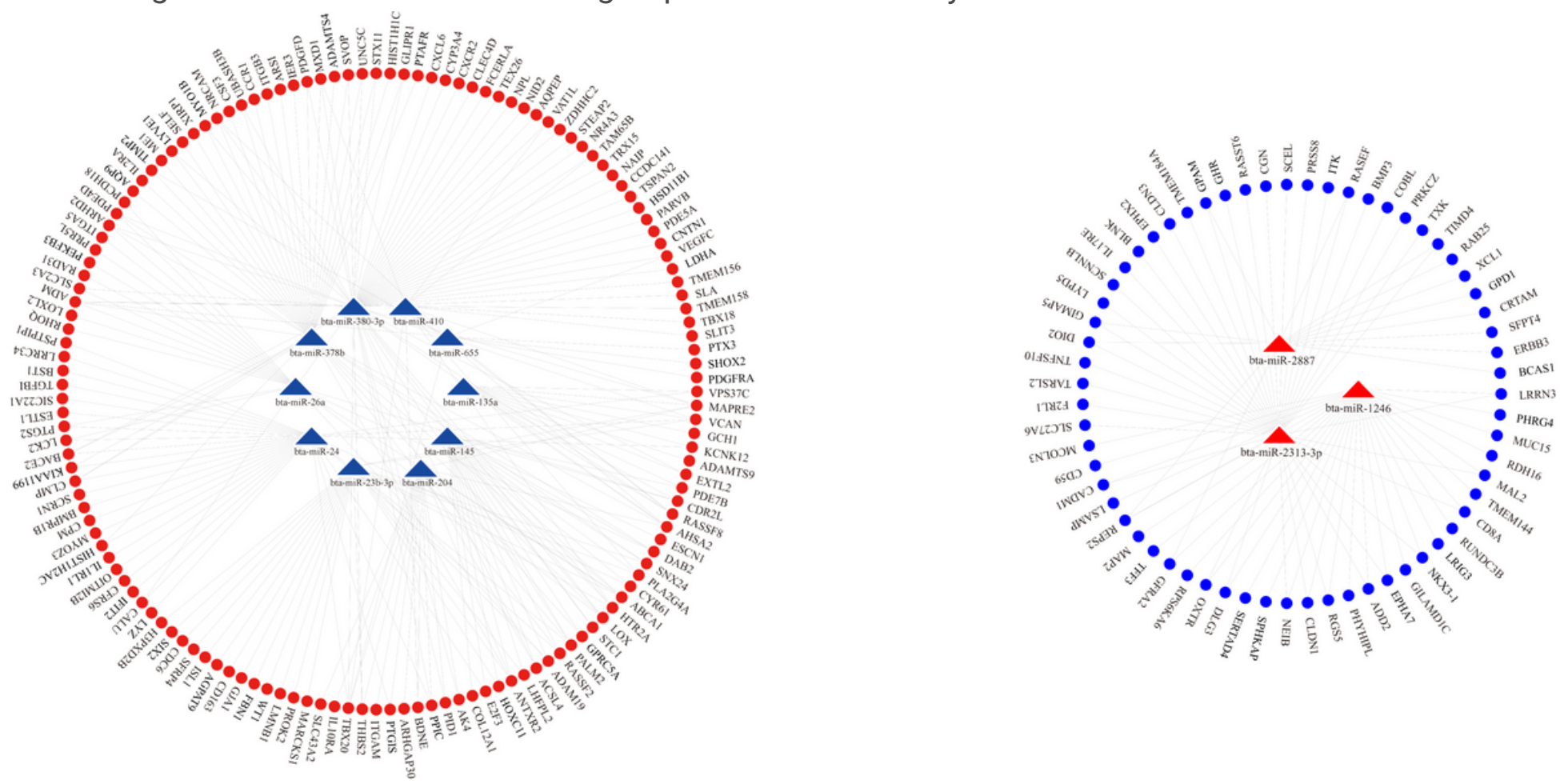

Figure 4

MiRNA-mRNA interaction networks. Red and blue triangles represent up-regulated and down-regulated miRNA in S. aureus- inoculated group, respectively. Red and blue circles represent up-regulated and downregulated DEGs in S. aureus- inoculated group, respectively.

A

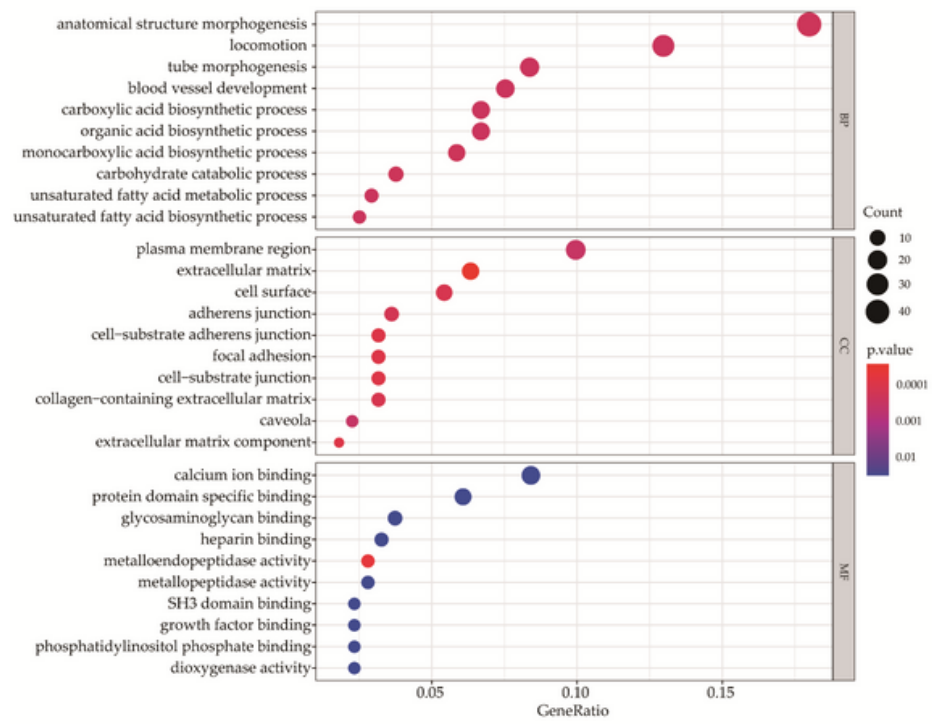

B

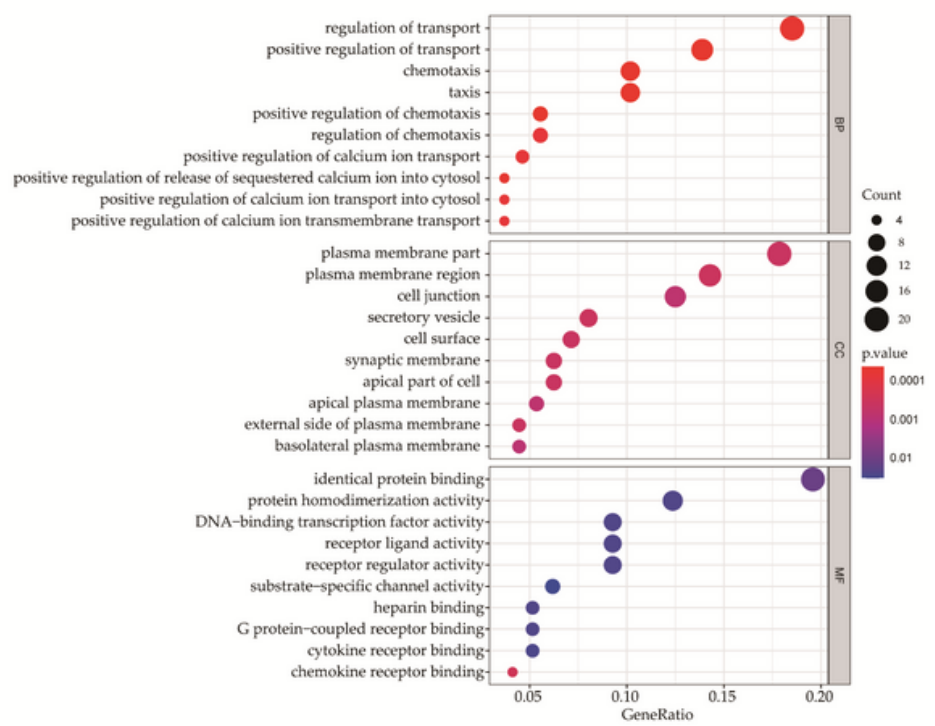

Figure 5 
GO functional enrichment analysis of DEGs. (A) Top 10 significant biological process, cellular component, and molecular function terms enriched by up-regulated DEGs. (B) Top 10 significant biological process, cellular component, and molecular function terms enriched by down-regulated DEGs.

A

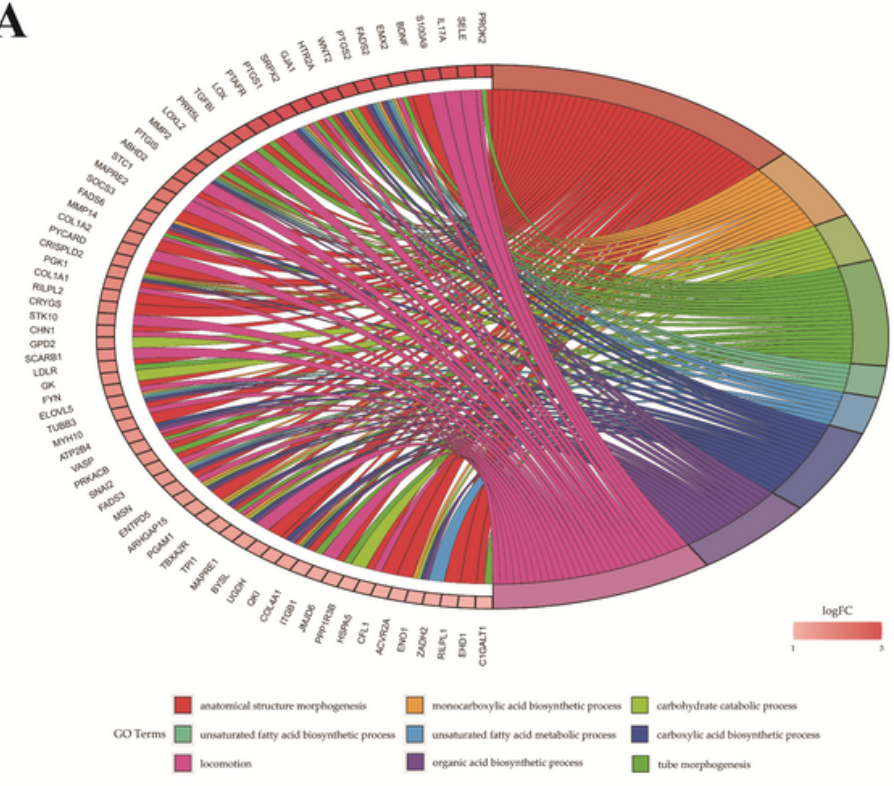

C

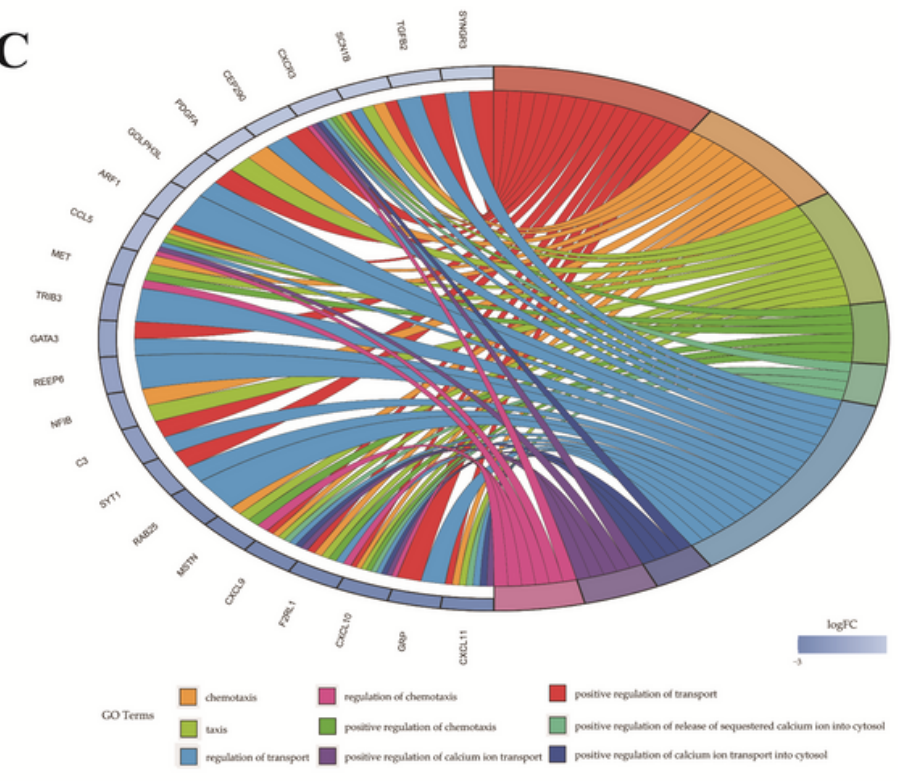

B

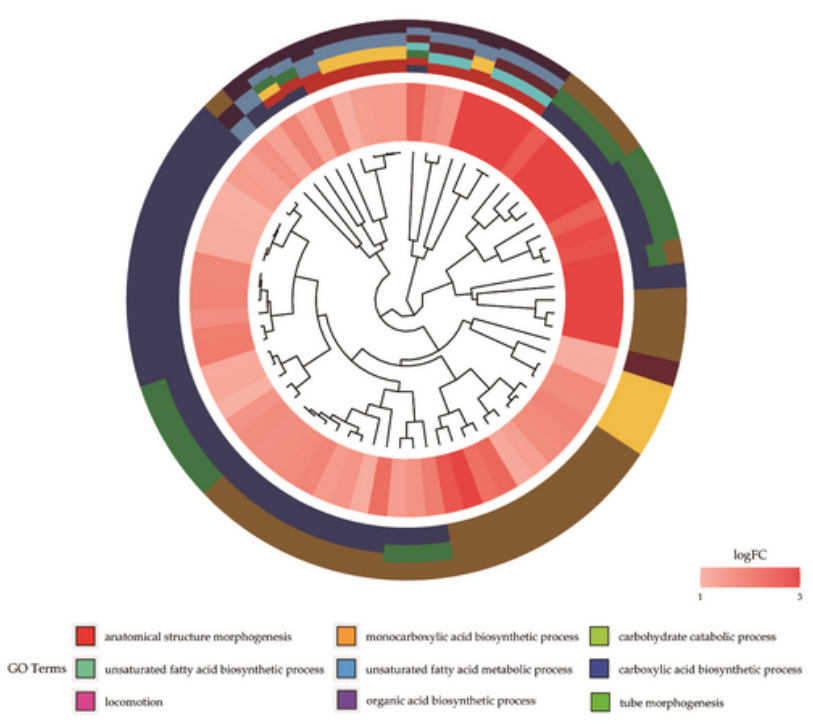

D

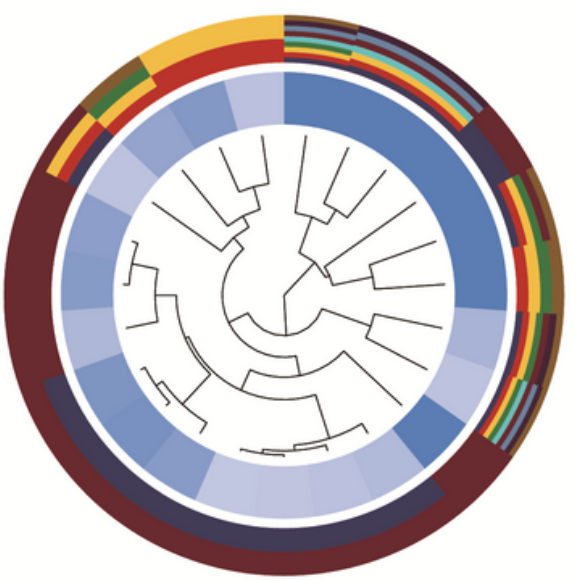

$\log \mathrm{FC}$

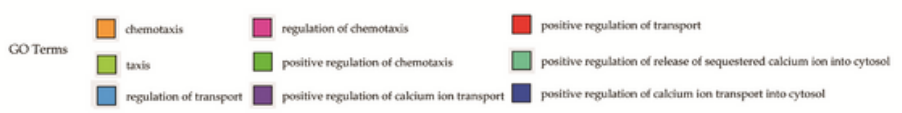

\section{Figure 6}

Features of DEGs enriched in top 9 significant GO terms. (A) Circos plots showed overlapping and specific responses of up-regulated DEGs. (B) Circos plots summarized features of up-regulated DEGs. (C) Circos plots showed overlapping and specific responses of down-regulated DEGs. (D) Circos plots summarized features of down-regulated DEGs. 
A

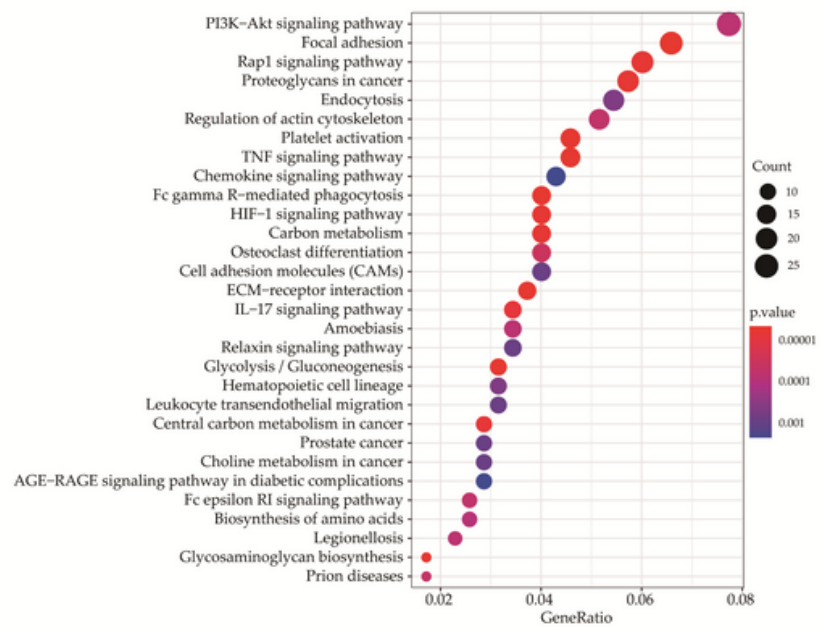

B

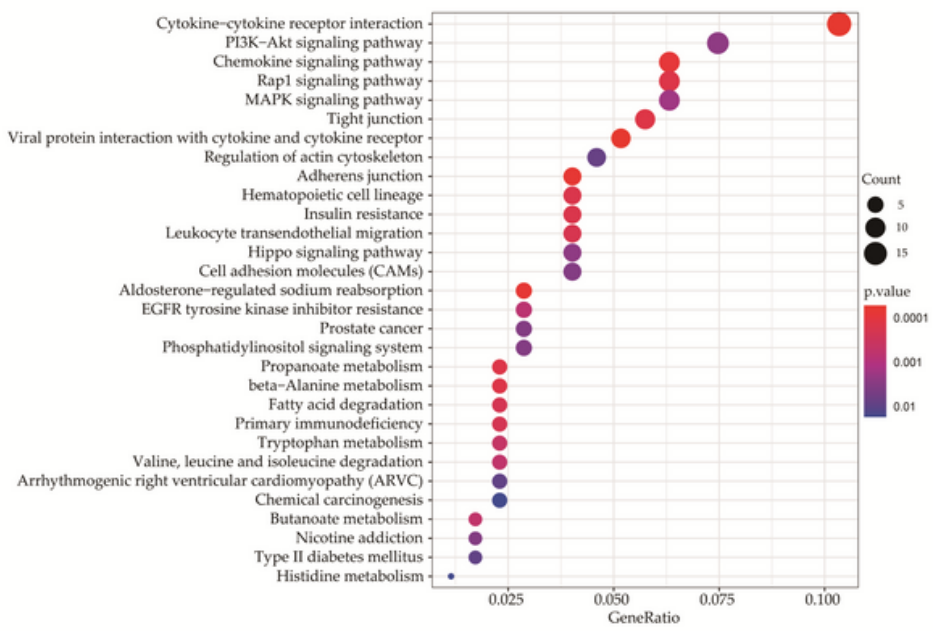

\section{Figure 7}

KEGG pathway analysis of DEGs. (A) Scatter plots of top 30 significant enriched KEGG pathways of upregulated DEGs. (B) Scatter plots of top 30 significant enriched KEGG pathways of down-regulated DEGs. 
A

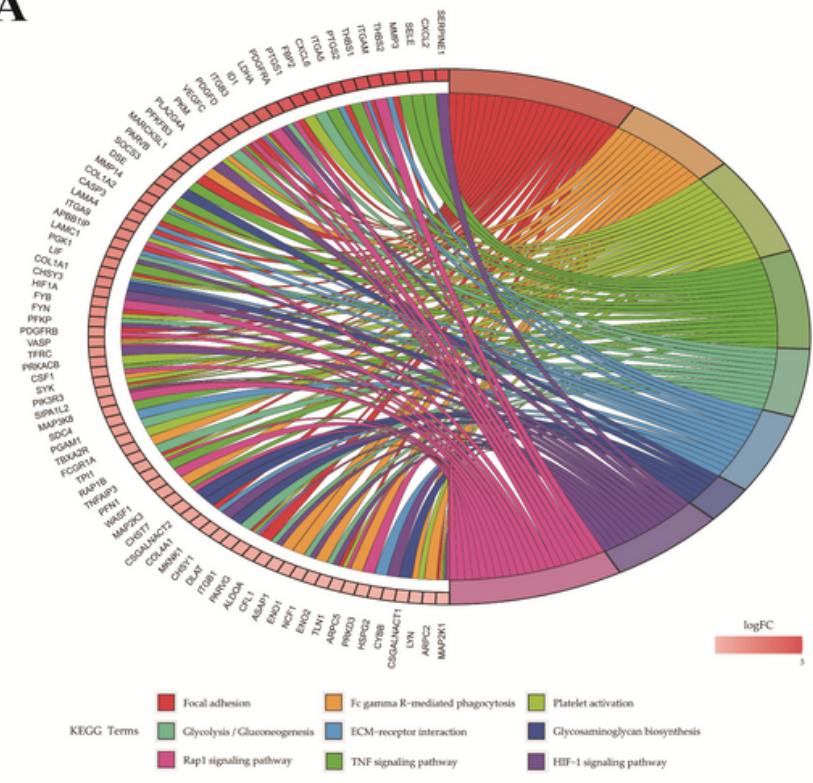

C

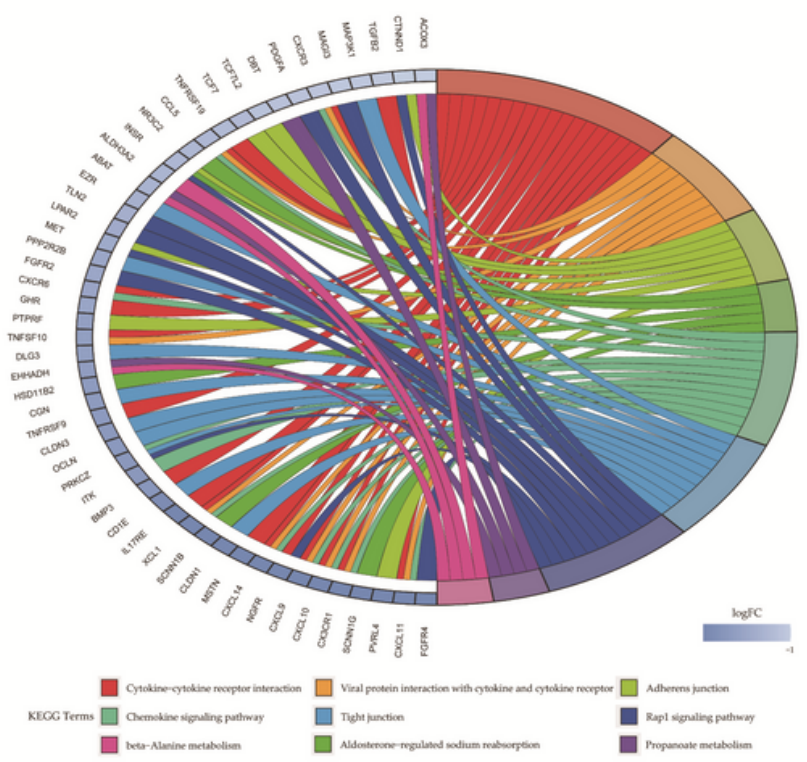

B
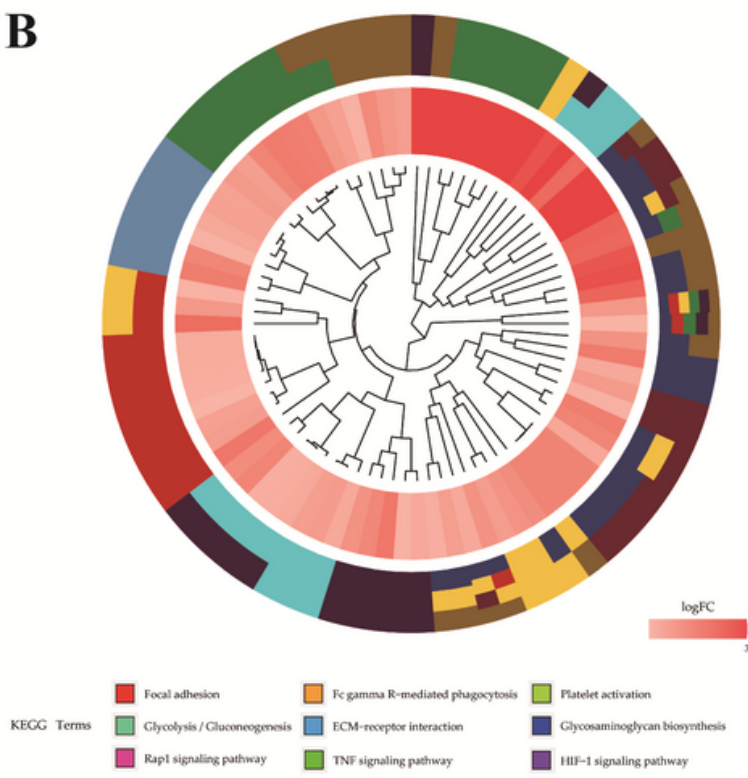

D

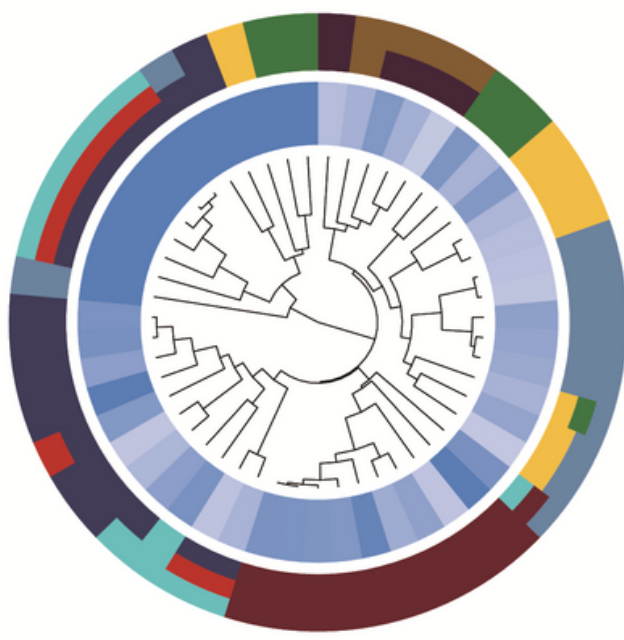

$\log \mathrm{FC}$

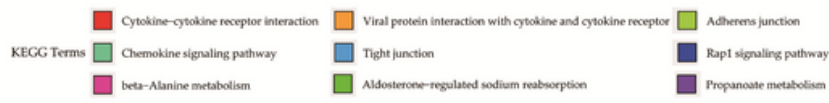

\section{Figure 8}

Features of DEGs enriched in top 30 significant KEGG pathways. (A) Circos plots showed overlapping and specific responses of up-regulated DEGs. (B) Circos plots summarized features of up-regulated DEGs. (C) Circos plots showed overlapping and specific responses of down-regulated DEGs. (D) Circos plots summarized features of down-regulated DEGs. 

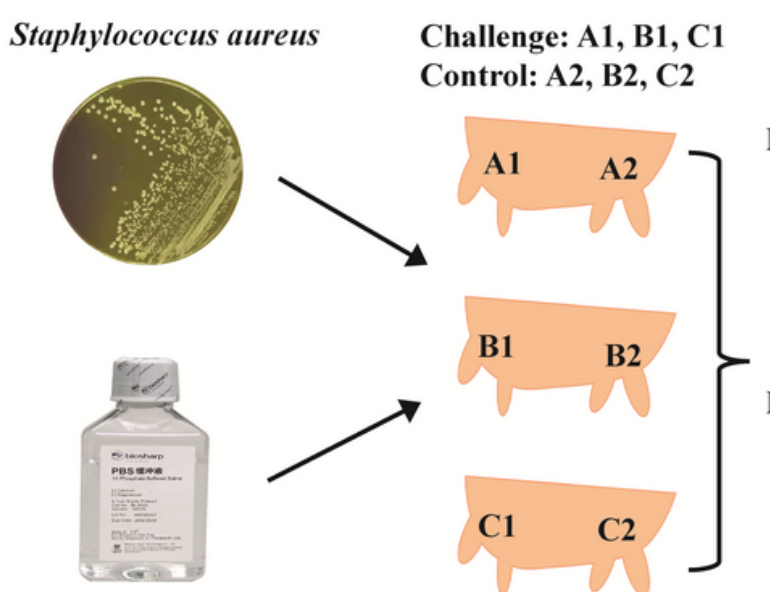

Mammary tissues from healthy cows
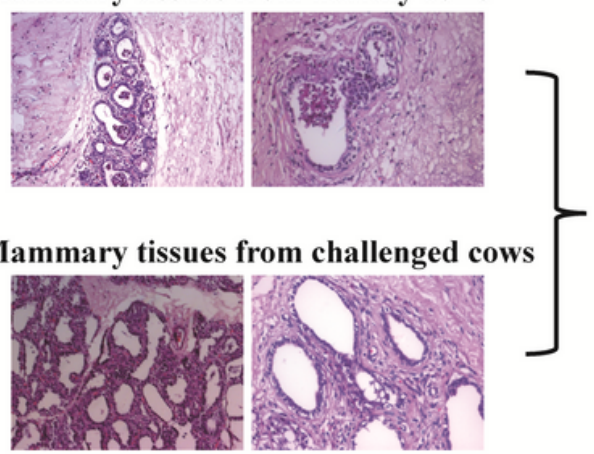

MiRNA sequencing: 77 DE miRNAs $(P \leq 0.05$, fold change $\geq 2)$

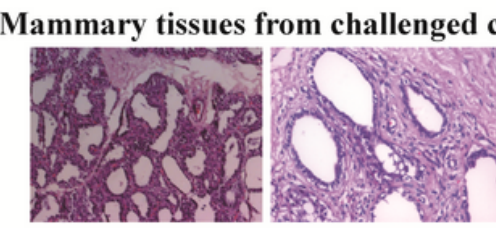

PBS solution

\section{Figure 9}

The construction of Staphylococcus aureus- induced mastitis and pathological features and integrative analysis of miRNA and mRNA expression profiles of mammary tissues.

\section{Supplementary Files}

This is a list of supplementary files associated with this preprint. Click to download.

- supplementarymaterials.docx 